\title{
STAVEBNÉ A FUNKČNÉ PREMENY HRADU MODRÝ KAMEŇ V 16. A 17. STOROČÍ
}

\author{
JÁN BELJAK - PAVOL MALINIAK - MICHAL ŠIMKOVIC
}

\begin{abstract}
Abstrakt: Na rozdiel od sporadických údajov z vrcholného a neskorého stredoveku, v 16. a 17. storoči disponujeme relativne početnými písomnými dokladmi o stavebnom usporiadani pôvodného jadra hradu Modrý Kameň. Obytné (veža, izby), hospodárske (komory, pivnice, studña) a sakrálne (kaplnka) objekty spomína del'ba hradu z roku 1527. O poškodení hradu vypovedajú správy o obliehaní z rokov 1575, 1588, 1593 a 1605. Podobu hradu so staršimi stavebnými etapami (zrejme turecký kúpel') aj s novovybudovanými čast’ami (napr. škola) približuje podrobná del'ba z roku 1625. Informácie z písomných prameňov sme verifikovali na základe archeologického a architektonicko-historického výskumu v rokoch 2013-2016.
\end{abstract}

Kl'účové slová: Modrý Kameň - gotický a renesančný hrad - vojenské konflikty - obnova - priestorové členenie.

\section{Building and Functional Transformations of Modrý Kamen̆ Castle in the 16th and 17th Centuries}

Abstract: In contrast to limited information from the high and late Middle Ages, there exists a relatively large number of written records from the 16th and 17th centuries about the building form of the core of the Modrý Kameñ castle. Residential quarters (tower, rooms), domestic amenities (pantries, cellar, well) and religious sections (chapel) are mentioned in a record on the spatial division of the castle from 1527. Damage to the castle is conveyed by records about sieges from the years 1575, 1588, 1593 and 1605. The form of the castle with early construction features (possibly a Turkish bath) and more recent parts (e.g. a school) is described in a detailed division from 1625. Information from written sources was verified on the basis of archaeological and architectural-historical research in 2013-2016.

Key words: Modrý Kameň castle - Gothic and renaissance castle - military conflicts - reconstruction spatial division.

\section{Úvod}

Príspevok je výsledkom interdisciplinárneho výskumu hradu Modrý Kameň, ktorý bol realizovaný v rámci prípravy pamiatkovej obnovy hradu v rokoch 2013-2015. Predstavuje základné vyhodnotenie doteraz realizovaných výskumov so zameraním na rekonštrukciu podoby hradu v období renesancie, teda v 16.-17. storočí. Problematika vývoja stredovekého hradu je vzhl’adom na prebiehajúci architektonicko-historický výskum načrtnutá len rámcovo.

\section{Poloha hradu}

Mesto Modrý Kameň sa nachádza v regióne Poiplia na juhu stredného Slovenska. Leží v doline potokov Krtíš a Riečka na južnom výbežku Krupinskej planiny. Rovnomenný hrad je situovaný v severnej časti obce na ostrožnom výbežku, vychádzajúcom z dominantného masívu Kalvárie (obr. 1). Dnešná dispozícia je trojdielna, pozostáva zo zrúcaniny stredovekého hradu obklopeného parkánom a tzv. dolného hradu, ktorý dnes tvorí trojkrídlový kaštiel' (obr. 2). Jadro hradu je výnimočným príkladom zrúcaniny, ktorej väčšina zástavby je prekrytá zásypom do výšky druhého podlažia. Súčasný stav je výsledkom úprav v druhej polovici 19. storočia, ked' bol horný hrad zmenený na park. Najvýraznejším pozostatkom v hornom hrade je obvodová hradba jadra (obr. 6:2) so vstupom a zvyškami paláca na juhovýchodnej strane (obr. 6:4). Obvodová hradba vytvorila plášt' zadržiavajúci sut’ové vrstvy z rozpadnutých budov. Pri úpravách horného hradu bol priestor jadra splanírovaný a zarovnaný hlinito-sut'ovou vrstvou. Vnútorný priestor bol rozčlenený do troch výškových úrovní s murovanými bočnými opornými múrmi. Najvyššie situovaná severovýchodná terasa je situovaná vo výške koruny hradby. Jednotlivé výškové úrovne sú spojené schodiskami. Dominantou jadra je relikt paláca na južnej a juhozápadnej strane (obr. 6:4), z ktorého sa zachovali dve obvodové steny do výšky necelých troch podlaží nad 


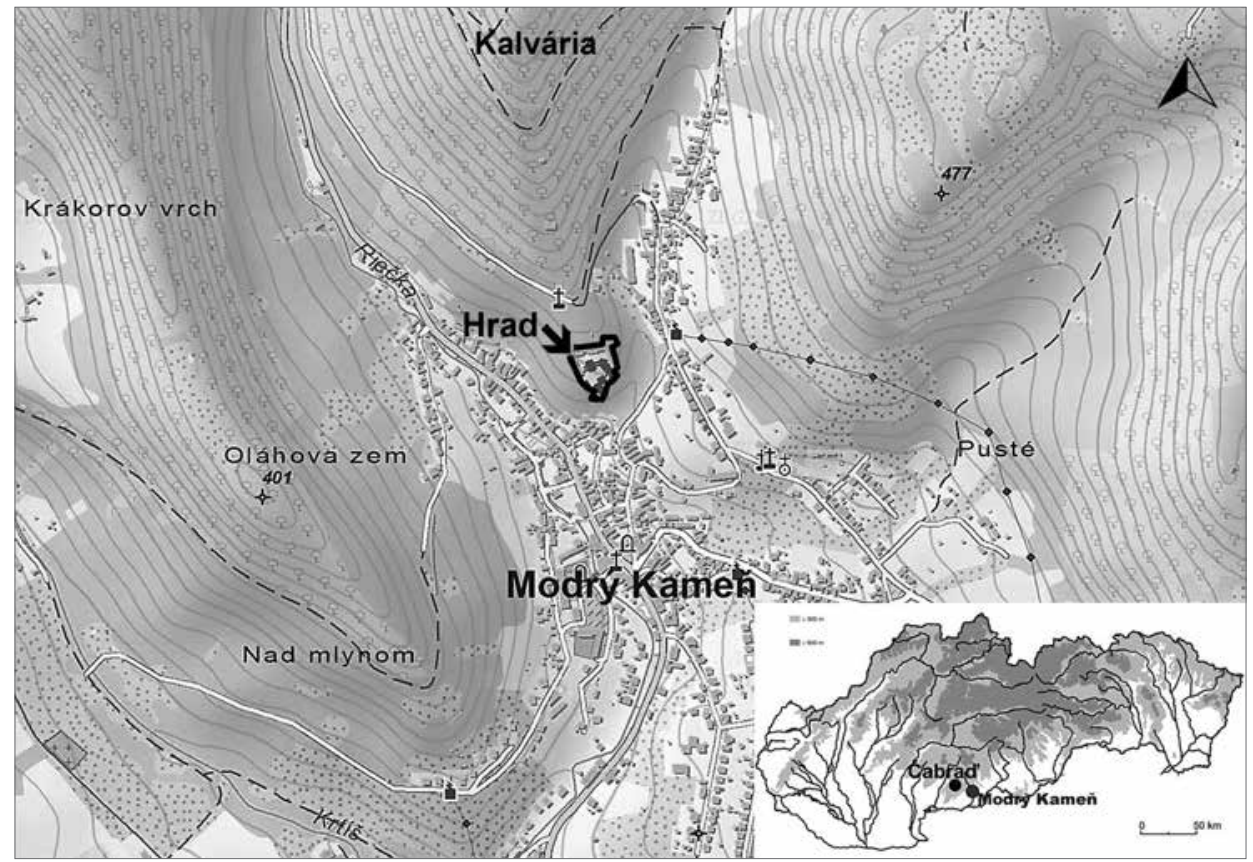

Obr. 1. Situovanie hradu Modrý Kameň nad rovnomenným mestom.

Abb. 1. Lage von Burg Blauenstein über der gleichnamigen Stadt.

úrovňou vnútorného nádvoria. Hradné jadro má obvod ca 200 metrov a zaberá plochu 0,25 ha. Stredný hrad tvorí severný a východný parkán a na dolnom hrade sa nachádza barokový kaštiel', s ktorým hrad disponuje celkovou rozlohou 0,6 ha.

\section{Dejiny bádania}

Názvu, tradíciám o vzniku, ako aj majitel'om hradu venoval medzi prvými pozornost' polyhistor Matej Bel. V časti o Modrom Kameni v rámci opisu Novohradskej stolice vo svojich Vedomostiach zároveň predstavil aj niektoré rozprávacie pramene týkajúce sa hradu počas osmanských vojen a stavovských povstaní (Bel 1742, 126-131).

Najstaršie známe dokumentácie hradu pochádzajú z 19. storočia. Dôležitým prameňom pre poznanie podoby hradu pred parkovými úpravami je ceruzkou nakreslený pôdorys od stavitel'a Karola Bergha, ktorý podnikol cestu do Novohradu v auguste 1862 (v roku 1866 ho prekreslil tušom). Sú na ňom ešte čitatel'né relikty pôvodnej zástavby, ako napríklad čast' vonkajšieho plášt’a obytnej veže s kruhovým pôdorysom a zvyšky d’alších, dnes už nezachovaných stavieb vo východnom parkáne i v hradnom jadre (obr. 3).

Ďalšiu dokumentáciu torza hradného jadra a stojacich častí novovekého kaštiela (pôdorys, pohl’ady z východu a zo západu) vyhotovil v roku 1889 pamiatkar Jozef Könyöki (Váliné Pogány 2000, 132, č. kat. 78.3-4). Zobrazuje stav hradu už po rozsiahlej parkovej úprave.

Podl'a moderného dejepisectva hrad založil v 30. rokoch 13. storočia zvolenský župan Detrik a následne ho dobudovali jeho potomkovia. Názory na počiatky hradu pred systematickým historickým výskumom v 20. storočí však neboli jednotné, pričom vychádzali z rôznych záverov, tradovaných najmä v literatúre (Borovszky 1911, 364; Aberty-Sloboda 1989, 136, 243). Aktuálne bádanie spája počiatky Modrého Kameňa s hradom šlachtica Petra (castrum comitis 


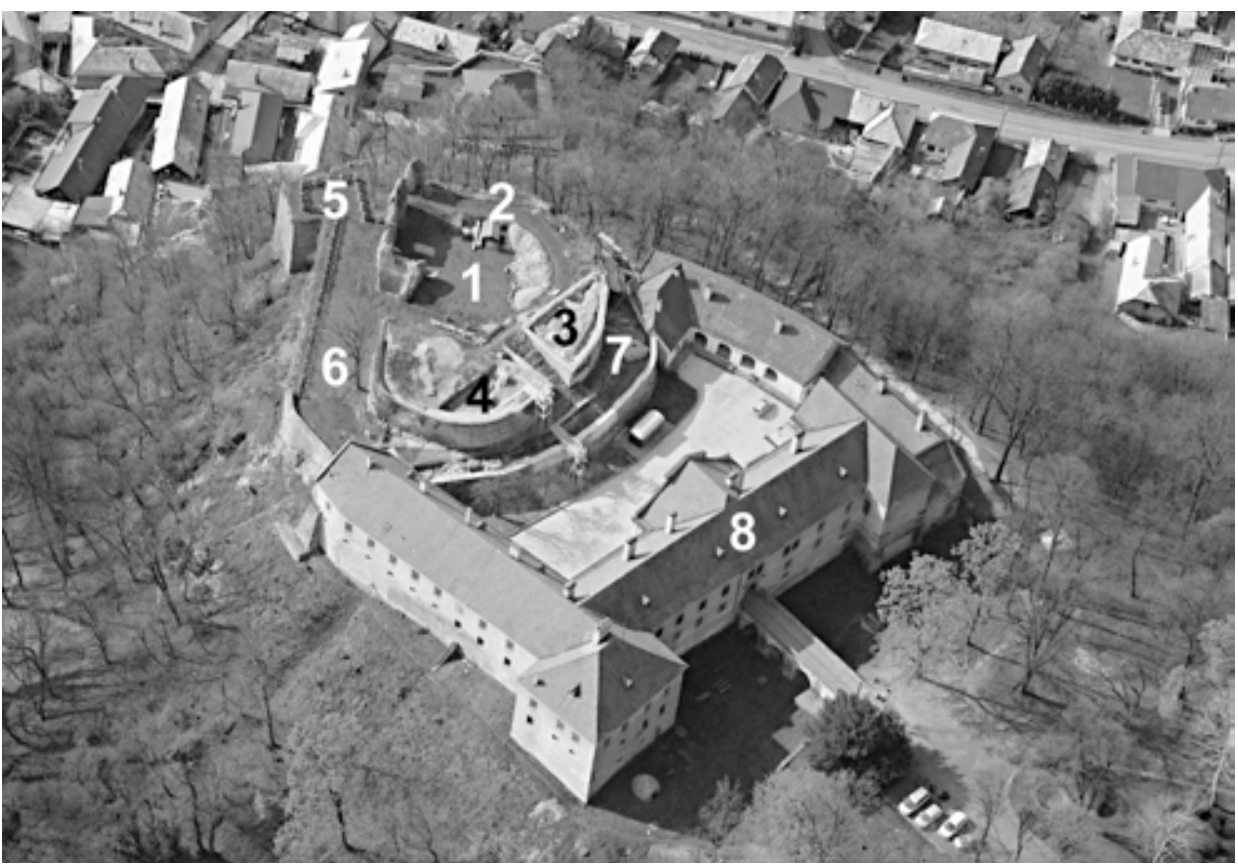

Obr. 2. Hrad Modrý Kameň, okr. Vel'ký Krtíš. Letecká snímka z roku 2014. Vyznačené sú hlavné hradné objekty. 1 - nádvorie horného hradu, 2 - západné krídlo paláca, 3 - valcová veža, 4 - severovýchodná terasa s hradnou kuchyňou, 5 - bastión, 6 - východný parkán, 7 - severný parkán (stredný hrad), 8 - barokový kaštiel' na mieste dolného hradu. Foto J. Beljak. Abb. 2. Burg Blauenstein, Bezirk Vel'ký Krtíš. Luftaufnahme aus dem Jahr 2014. Gekennzeichnet wurden die Hauptobjekte der Burg. 1 - Hof der oberen Burg, 2 - Westflügel des Palas, 3 - zylinderförmiger Turm, 4 - Nordostterrasse mit Burgküche, 5 - Bastion, 6 - östlicher Zwinger, 7 - nördlicher Zwinger (mittlere Burg), 8 - Barockschloss an der Stelle der unteren Burg. Foto J. Beljak.

Petri), doloženým v roku 1278 pri opise hraníc medzi majetkami Strháre a Osláre. Spomínaný Peter, prezývaný aj Forró, patril k potomkom župana Detrika (Fügedi 1977, 149; Plaček-Bóna 2007, 207; Sitár 2016, 37-39).

\section{Architektonicko-historický a archeologický výskum}

Prvý detailný architektonicko-historický výskum zrúcaniny bol realizovaný M. Šimkovicom v rámci čiastkovej pamiatkovej obnovy v roku 1998. Vyvolaná bola zlým stavom juhovýchodnej steny paláca horného hradu, ktorá predstavuje najhodnotnejší nadzemný relikt s množstvom architektonických detailov. Výsledky výskumu boli publikované v stručnej forme (Šimkovic 2000, 184). K poznaniu vývoja hradného jadra zásadným spôsobom prispel archeologický výskum AÚ SAV v Nitre v rokoch 2013-2016 pod vedením J. Beljaka v spolupráci so Z. Kaličiakovou, P. Debnárom a M. Holeščákom (Beljak-Mordovin-Šimkovic-Kaličiaková 2016, 277-282). V sezóne 2013 sa výskum realizoval plošne do hĺbky jedného metra na severozápadnej a severovýchodnej terase hradného jadra s ciel'om odstránit' vlhnutie muriva opevnenia hradu. Priestor severného parkánu sa preskúmal až po geologické podložie (obr. 4-5).

V roku 2014 bolo v prvej fáze výskumu odkrytých pät’ sond pri západnej línii obvodového opevnenia hradného jadra s ciel'om zachytit' priebeh jeho vnútorného líca (obr. 6). Ďalej boli odkryté dve sondy vo východnej a v južnej časti východnej terasy, ktorých ciel'om bolo zistit' hrúbku a kondíciu východnej línie opevnenia a stratigrafiu vrstiev v jeho susedstve. Jedna sonda 


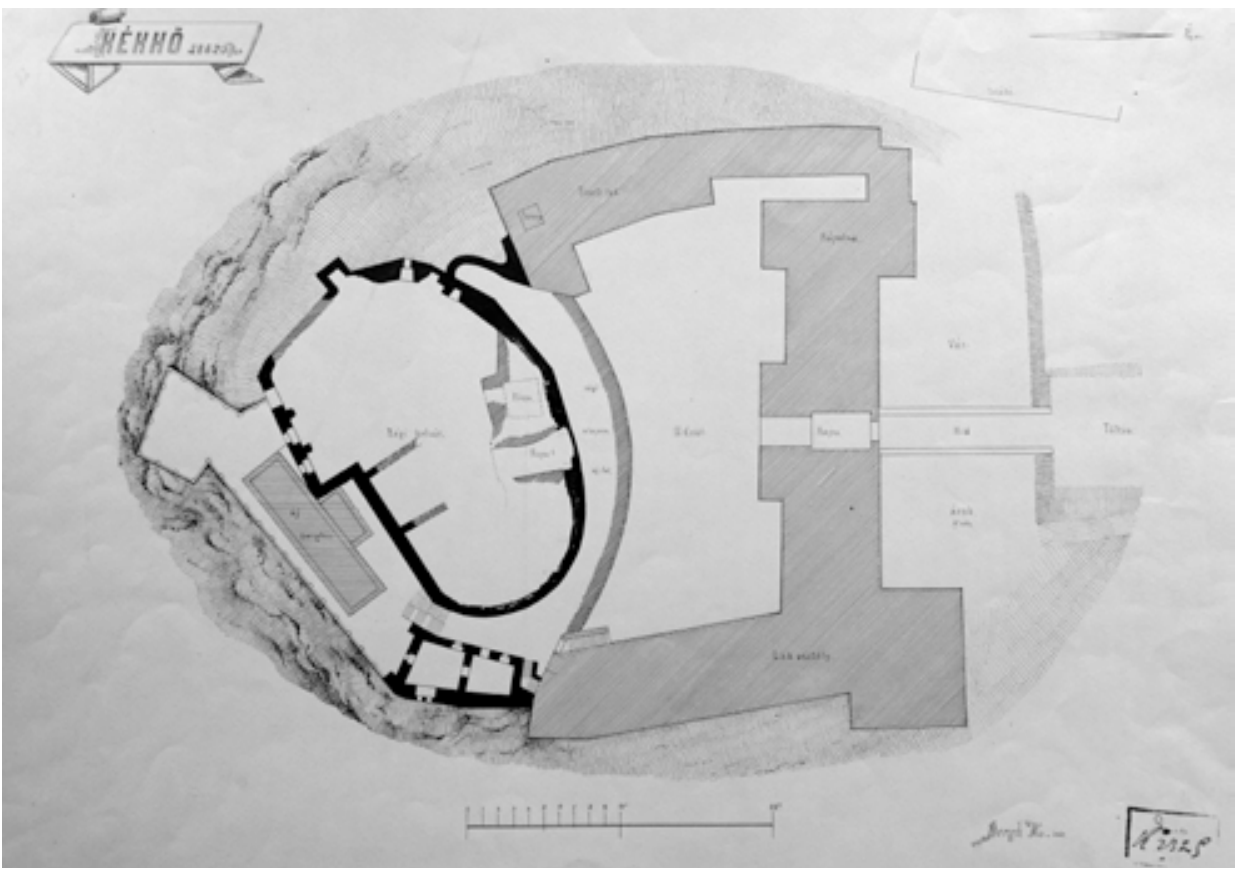

Obr. 3. Hrad Modrý Kameň, okr. Vel'ký Krtíšs. Kresba Karola Bergha zachytávajúca pôdorys hradu v roku 1862. Zdroj Forster Gyula Nemzeti Örökségvédelmiés Vagyongazdálkodási Központ.

Abb. 3. Burg Blauenstein, Bezirk Vel'ký Krtís. Karl Berghs Zeichnung zeigt den Grundriss der Burg im Jahr 1862. Quelle Forster Gyula Nemzeti Örökségvédelmiés Vagyongazdálkodási Központ.

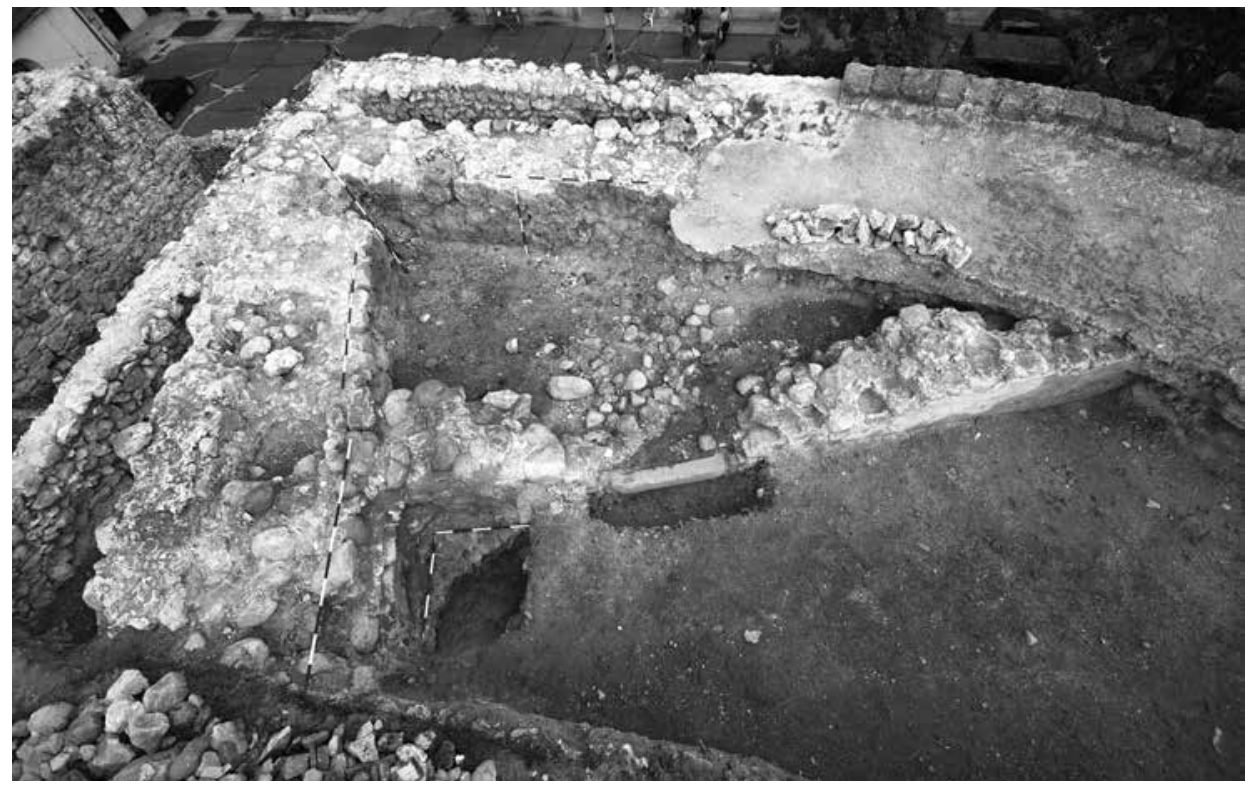

Obr. 4. Hrad Modrý Kameň, okr. Vel'ký Krtíš. Severovýchodná terasa so stredovekým opevnením a renesaněnou kuchyňou počas výskumu v roku 2013. Foto J. Beljak.

Abb. 4. Burg Blauenstein, Bezirk Vel'ký Krtíš. Nordostterrasse mit mittelalterlicher Befestigung und renaissancezeitlicher Küche während der Grabung im Jahr 2013. Foto J. Beljak. 


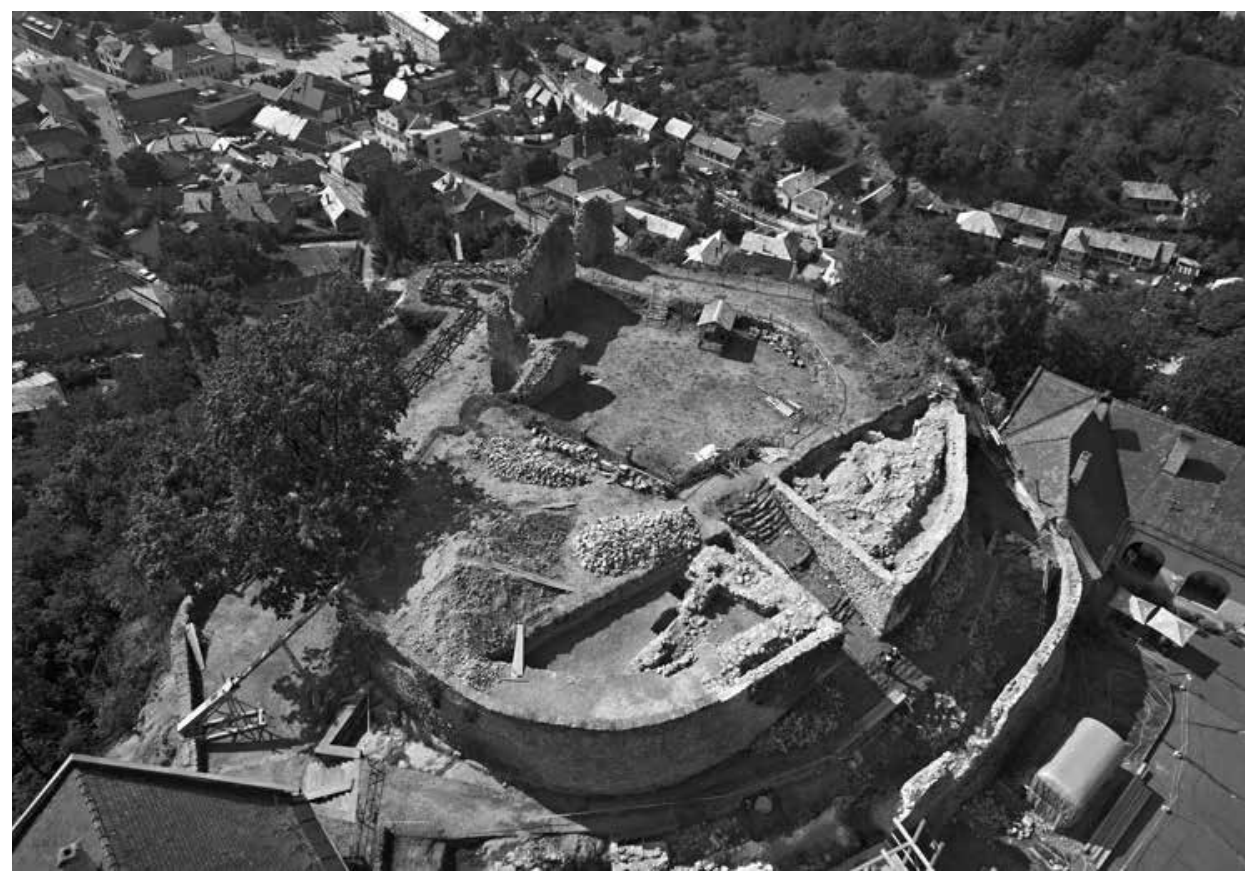

Obr. 5. Hrad Modrý Kameň, okr. Vel'ký Krtíš. Hradné jadro (horný a stredný hrad) s výskumom odkrytou architektúrou na severovýchodnej a severozápadnej terase a severným parkánom v roku 2013. Foto J. Ornth.

Abb. 5. Burg Blauenstein, Bezirk Vel'ký Krtíš. Kernburg (Ober- und Mittelburg) mit bei der Grabung freigelegter Architektur auf der Nordost- und Nordwestterrasse und nördlicher Zwinger im Jahr 2013. Foto J. Ornth.

bola odkrytá v priestore zaniknutého južného krídla paláca v blízkosti vstupnej brány do hradu. Kvôli zemným prácam pre realizáciu kanalizácie boli v priestore východnej časti parkánu a na dolnom nádvorí odkryté d’alšie dve sondy.

V roku 2015 bolo na hrade Modrý Kameň zrealizovaných pät’ archeologických sond. Ako sondu č. 6/2015 používame pracovné pomenovanie pre začistenie torza muriva pri západnej línii opevnenia hradného jadra, ktoré bolo dočistené pri budovaní lešenia pri jeho vonkajšom líci. Prvé dve sondy boli situované na severovýchodnej terase. Za úlohu mali odhalit' priebeh východnej a južnej línie obvodového múru (obr. 7). Ďalšie sondy boli v sezóne 2015 situované pri západnej línii opevnenia. Nadväzovali na sondy z roku 2014 a ich účelom bolo zistit’ spôsob napojenia objavených múrov a začistenie prévetu odkrytého v západnej línii opevnenia. Pri väčšine sond sa kopalo do híbky približne $100 \mathrm{~cm}$, pri začistovaní prévetu bola dosiahnutá híbka takmer 3 metre.

V sezóne 2016 sme s výskumom pri západnej línii opevnenia pokračovali a doskúmali sme nálezovú situáciu v priestore prévetu (obr. 8). Ďalšou sondou sme odhalením klenby a múru pod východnou terasou získali informácie o štruktúre hradu. Zrejme ide o pokračovanie predpokladaného kuchynského traktu z renesančnej prestavby hradu a múr tvoril jeho západnú fasádu smerom na nádvorie.

\section{Stredoveký hrad}

Hrad, uvádzaný od roku 1290 ako Modrý Kameň, resp. v mad’arskom znení Kékkő (castrum Keykkw), zostal v rukách Petrových príbuzných, ktorí v 14. storočí používali predikát 


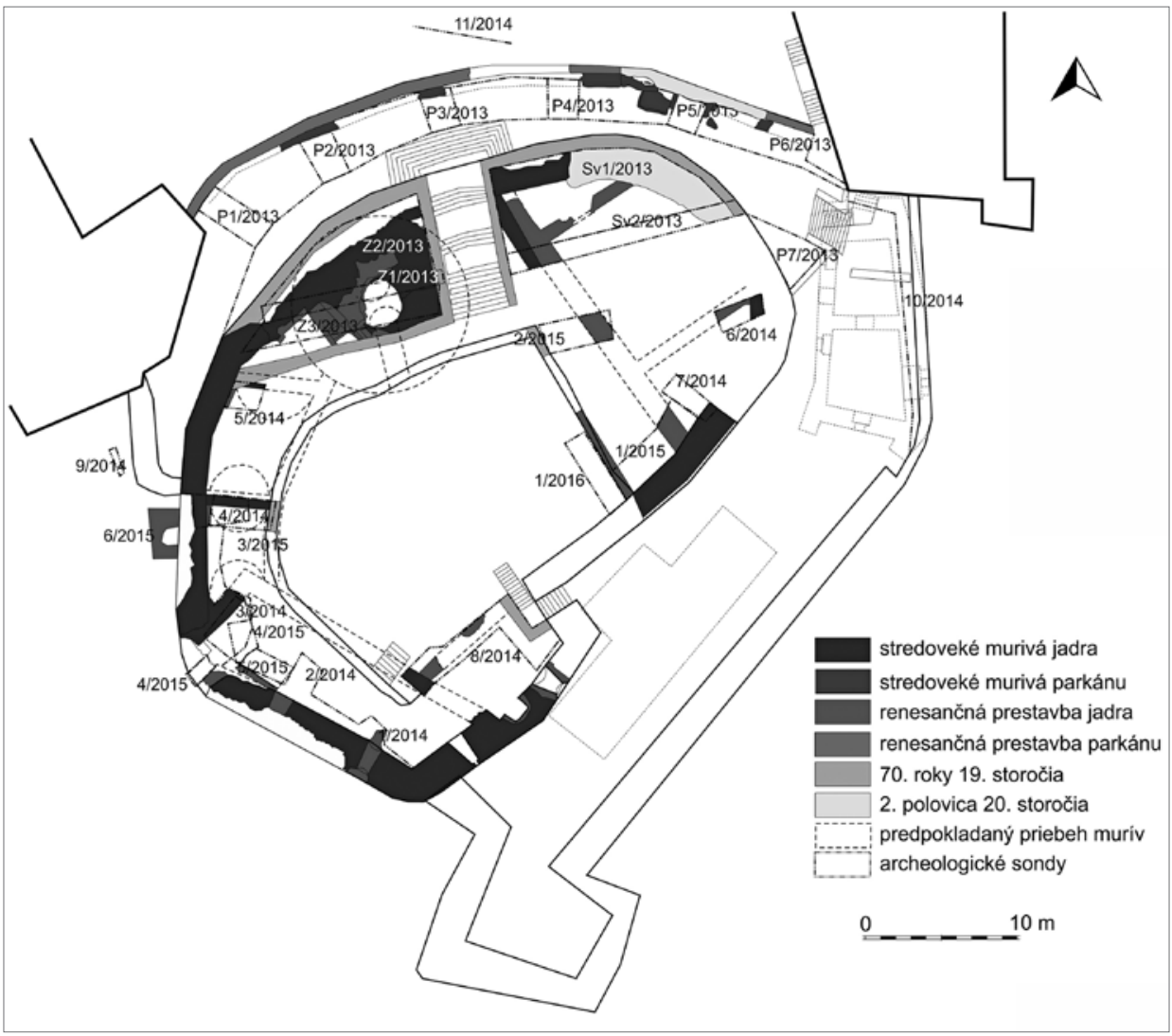

Obr. 6. Hrad Modrý Kameň, okr. Vel'ký Krtíš. Pôdorys jadra s architektonicko-historickým vyhodnotením odkrytej architektúry hradného jadra, umiestnením archeologických sond z rokov 2013-2016 a označením objektov. 1 - veža, 2 - hradba jadra, 3 - vstupná brána jadra, 4 - juhovýchodné krídlo paláca, 5 - juhozápadné krídlo paláca, 6 - západné krídlo paláca, 7 - renesančné severné krídlo na mieste veže, 8 - severovýchodné krídlo budov jadra, 9 - parkánová hradba, 10 - brána do parkánu. Legenda: A - stredovek (13.-15. storočie), B, C, D - renesancia, 16.-17. storočie, E - 19.-20. storočie, F - archeologické sondy, čiarkovane predpokladaný priebeh murív. Vyhotovili M. Šimkovic, J. Beljak, A. Loydl.

Abb. 6. Burg Blauenstein, Bezirk Vel'ký Krtíš. Grundriss der Kernburg mit bauhistorischer Auswertung der freigelegten Architektur der Kernburg, Lage der archäologischen Sondierschnitte aus den Jahren 2013-2016 und Bezeichnung der Objekte. 1 - Turm, 2 - Wehrmauer der Kernburg, 3 - Eingangstor der Kernburg, 4 - Südostflügel des Palas, 5 - Südwestflügel des Palas, 6 - Westflügel des Palas, 7 - renaissancezeitlicher Nordflügel an der Stelle des Turms, 8 - Nordostflügel der Gebäude der Kernburg, 9 - Zwingermauer, 10 - Tor zum Zwinger. Legende: A - Mittelalter (13.-15. Jhdt.), B, C, D - Renaissance, 16.-17. Jhdt., E - 19.-20. Jhdt., F - archäologische Sondierschnitte, gestrichelt - mutmaßlicher Mauerwerksverlauf. Erstellt von M. Šimkovic, J. Beljak, A. Loydl.

z Modrého Kameňa. Od roku 1375 členovia rodu podl’a predikátu striedavo sídlili aj v Ďarmotách (dnes Balassagyarmat), kam sa zrejme postupne prest'ahovali (Fekete Nagy-Borsa 1990, 25, 57, 66-67, č. 54, 150, 151, 182, 186; Hanko 2012, 33-38). V období rozbrojov po smrti Žigmunda Luxemburského mohol byt' hrad nad’alej funkčný. V roku 1444 sa šahanský prepošt st’ažoval na Mikulášovho syna Ladislava, ktorý aj so svojimi bratmi ešte v predchádzajúcom roku obsadil a opevnil kláštor v Šahách a prepoštovu dedinu Plachtince násilím pripojil medzi príslušenstvá k ich hradu Modrý Kameň (ad castrum ipsorum Kekkw) (MNL DL 13 806; Fekete Nagy-Borsa 1990, 107, č. 315). Spomedzi majitel'ov v neskorom stredoveku práve spomínaný Ladislav začal podl'a svojho starého otca Blažeja (Balázsa) používat' prímeno Balassa, prípadne Balassi, ktoré prevzali a až do 19. storočia používali aj nasledujúci členovia rodu (Horváth 2013, 40-41). Na 


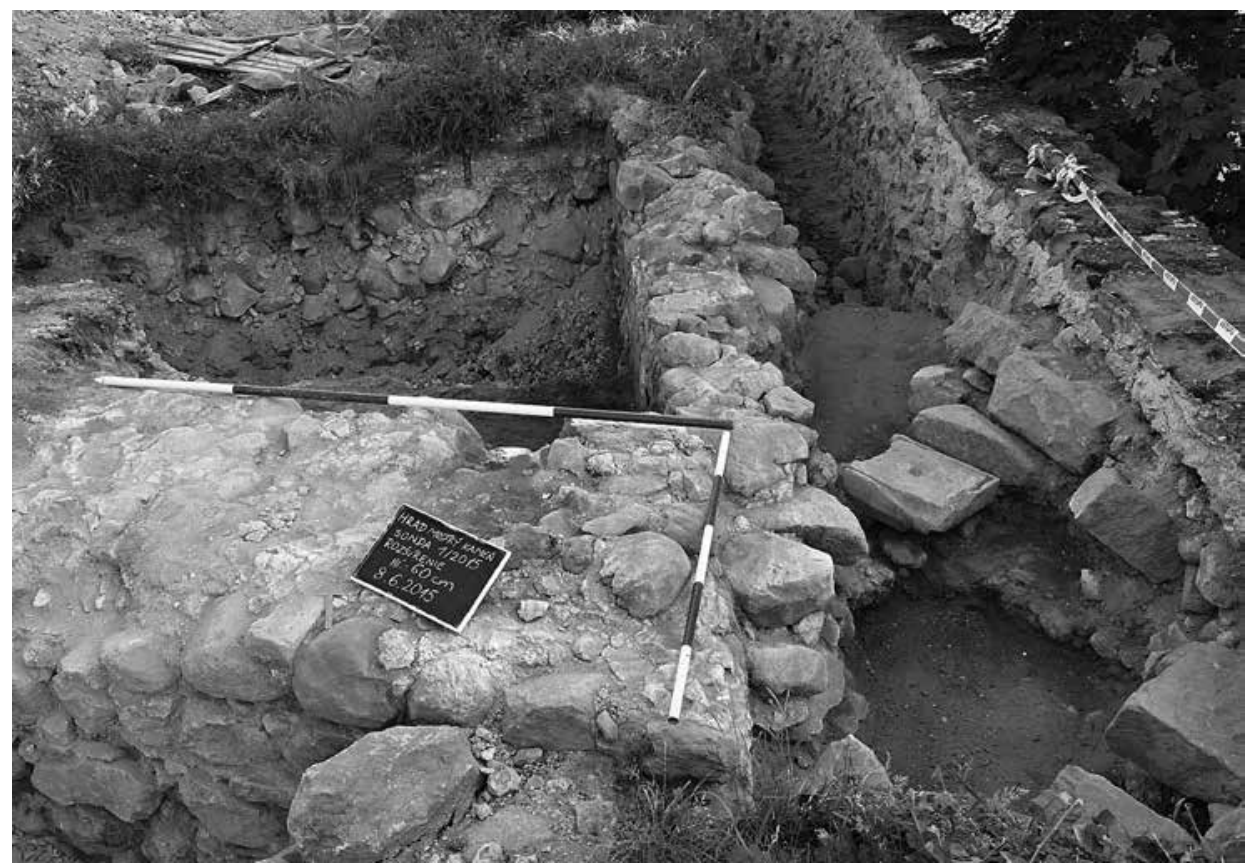

Obr. 7. Hrad Modrý Kameň, okr. Vel'ký Krtíš. Kontakt stredovekého opevnenia s murivom renesančného traktu, odkrytý sondou 1/2015 v priestore juhovýchodnej terasy. Foto Z. Kaličiaková.

Abb. 7. Burg Blauenstein, Bezirk Vel'ký Krtíš. Kontakt der mittelalterlichen Befestigung mit dem Mauerwerk des Renaissancetraktes, freigelegt mit Sondierschnitt 1/2015 im Bereich der Südostterrasse. Foto Z. Kaličiaková.

základe používaného predikátu a tiež podl’a datovania vydaných listov možno usudzovat', že Ladislavov syn František sídlil pri pobyte na svojich novohradských majetkoch v závere stredoveku v Ďarmotách, kde dal postavit' kaštiel' (MNL DF 235 552, 267 106, 271 638; Horváth 2013, 42).

Zo stredovekého hradu z 13. storočia sa zachovala obvodová hradba (obr. 6:2), ktorá vymedzovala oválny pôdorys hradu $(46 \times 32 \mathrm{~m})$ so zalomením hradby na východnej strane v mieste vstupnej brány (obr. 6:3). Súčastou pôvodného hradu bola zrejme aj mohutná valcová veža vybudovaná v čele dispozície na severnej strane (obr. 6:1,9). Veža s vnútorným priemerom interiéru $3 \mathrm{~m}$ a hrúbkou muriva minimálne $2,5 \mathrm{~m}$ čiastočne vystupovala $\mathrm{z}$ línie opevnenia.

Pravdepodobne v priebehu 14. storočia došlo k vybudovaniu stredovekého hradného paláca (obr. 6:5). Obytná stavba približne obdížnikového pôdorysu zabrala priestor pozdíž juhozápadného úseku opevnenia. Výskumy zistili čiastočne zachované pravouhlé gotické okienko v blízkosti južného nárožia a zvyšky d’alších podobných okien na juhozápadnej strane (obr. 10).

Medzi mladšie stredoveké úpravy je možné zaradit' niekol'ko d’alších prestavieb. Do tohto obdobia zrejme patrí vybudovanie parkánu (obr. 6:9), ktorý na prístupovej strane zosilnil opevnenie hradu. Z pôvodnej subtílnej hradby výskum zachytil len nepatrné zvyšky. K parkánovej hradbe bola dodatočne pristavaná dovnútra otvorená stavba $\mathrm{s}$ vnútornou šírkou $3 \mathrm{~m}$, ktorú je možné predbežne interpretovat' ako bránovú vežu (obr. 6:10). Šachta v jej interiéri je zrejme zvyškom brány chránenej tzv. kolískovým padacím mostom (obr. 11).

Do rámca stredovekých alebo neskorostredovekých prestavieb hradu je možné zaradit' obnovu pôvodnej veže (obr. 6:1). Jej vonkajšia čast' bola v dôsledku dobýjania hradu alebo statickej poruchy kompletne zbúraná a znova vybudovaná. Aj po obnove sa na stavbe prejavili statické poruchy v podobe zvislých trhlín na východnej a západnej strane. Spolu s vežou bolo výrazne prestavané opevnenie na čelnej strane hradu. Novovybudovaná masívna hradba 


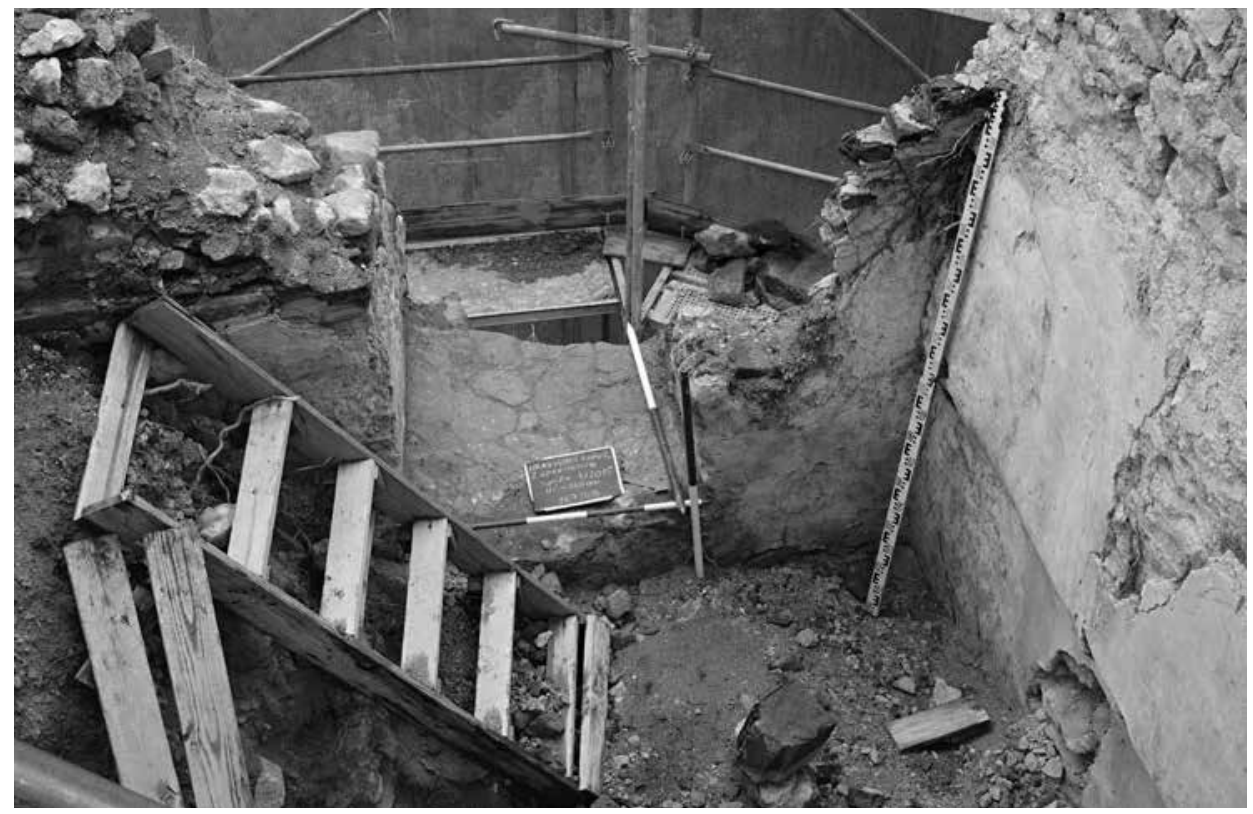

Obr. 8. Hrad Modrý Kameň, okr. Vel’ký Krtís.s. Prevét v západnej línii opevnenia hradu, odkrytý sondou 4/2015. Foto Z. Kaličiaková.

Abb. 8. Burg Blauenstein, Bezirk Vel'ký Krtíš. Abort in der Südflucht der Burgbefestigung, freigelegt mit Sondierschnitt 4/2015. Foto Z. Kaličiaková.

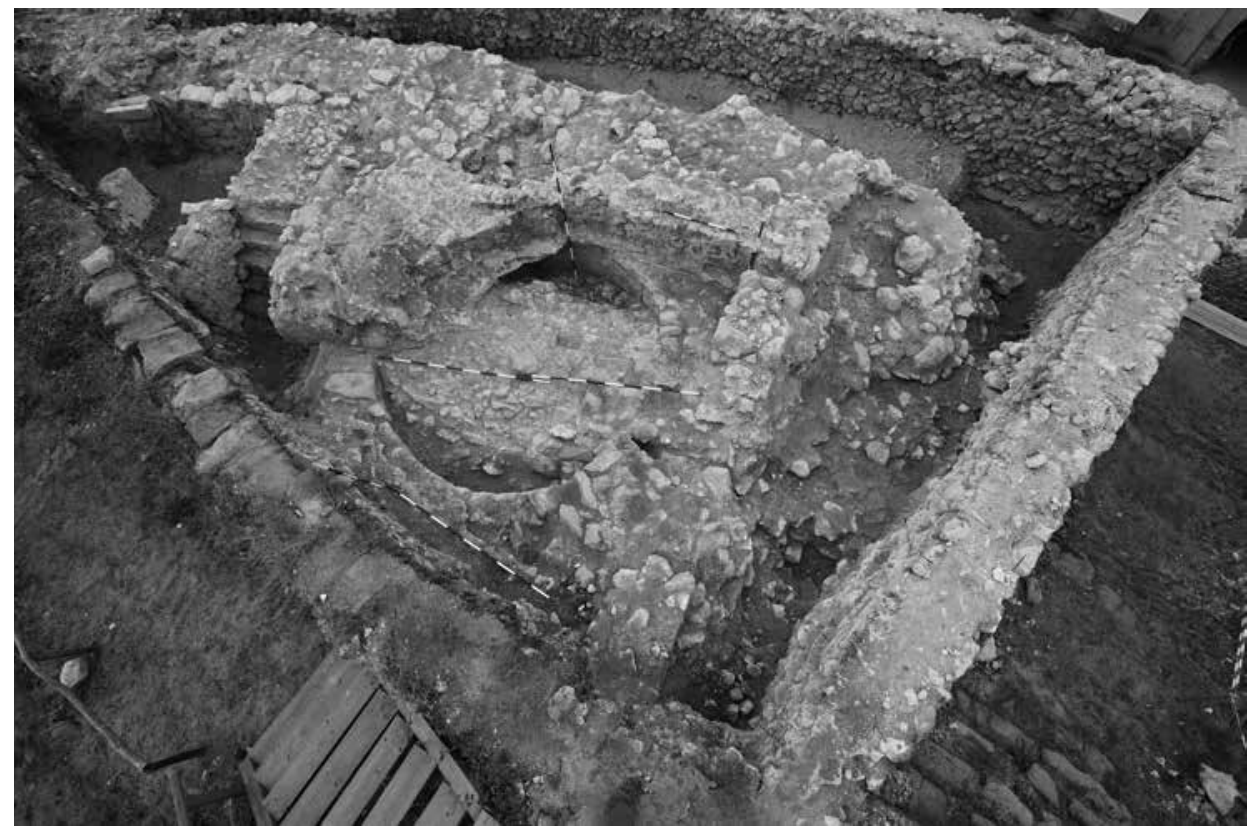

Obr. 9. Hrad Modrý Kameň, okr. Vel’ký Krtíš. Severozápadná terasa so stredovekou valcovou vežou, renesančnými múrmi, schodiskami a terasovými múrmi z 19. storočia počas výskumu v roku 2013. Foto J. Beljak.

Abb. 9. Burg Blauenstein, Bezirk Vel'ký Krtíš. Nordwestterrasse mit mittelalterlichem zylinderförmigen Turm, Renaissancemauern und Terrassen aus dem 19. Jhdt. Während der Grabung im Jahr 2013. Foto J. Beljak. 


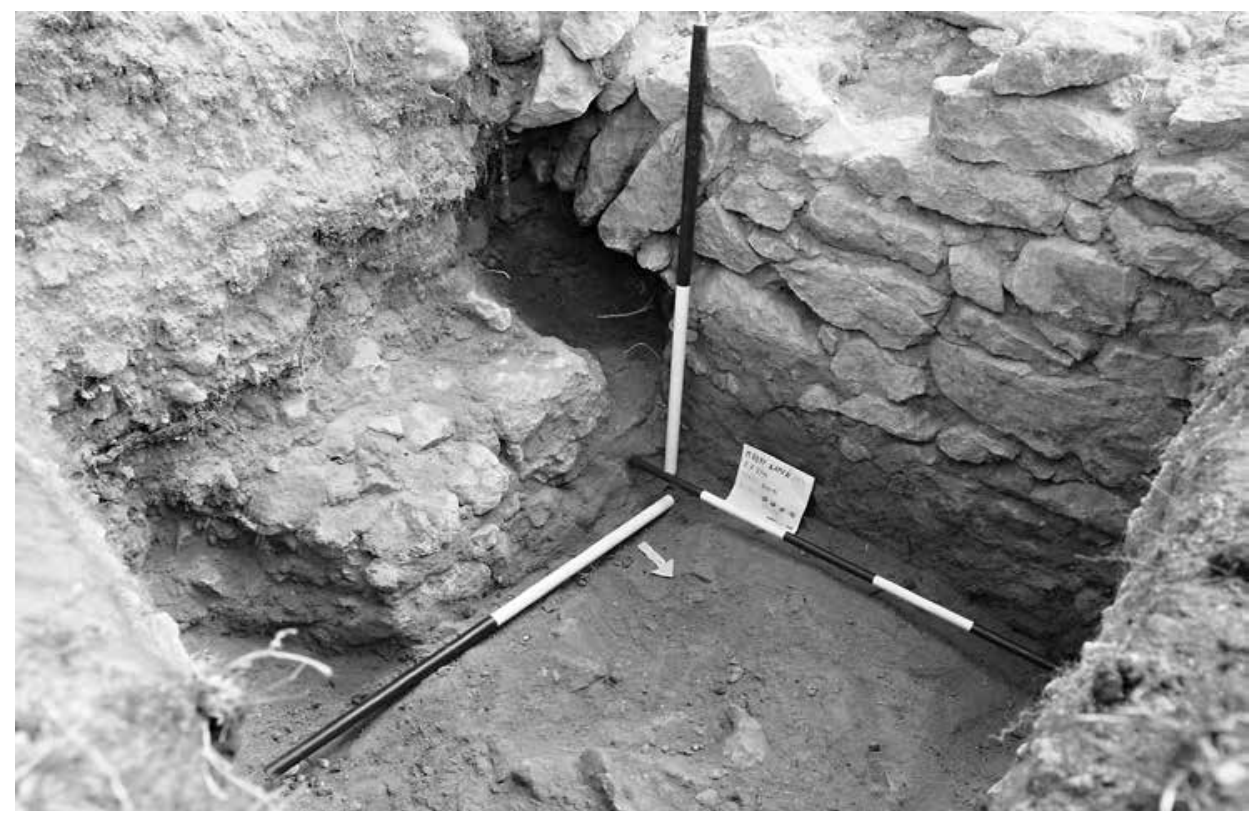

Obr. 10. Hrad Modrý Kameň, okr. Vel'ký Krtíš. Okno juhovýchodného paláca, odkryté sondou 1/2014. Foto P. Debnár. Abb. 10. Burg Blauenstein, Bezirk Vel'ký Krtíš. Fenster des Südostpalas, freigelegt mit Sondierschnitt 1/2014. Foto P. Debnár.

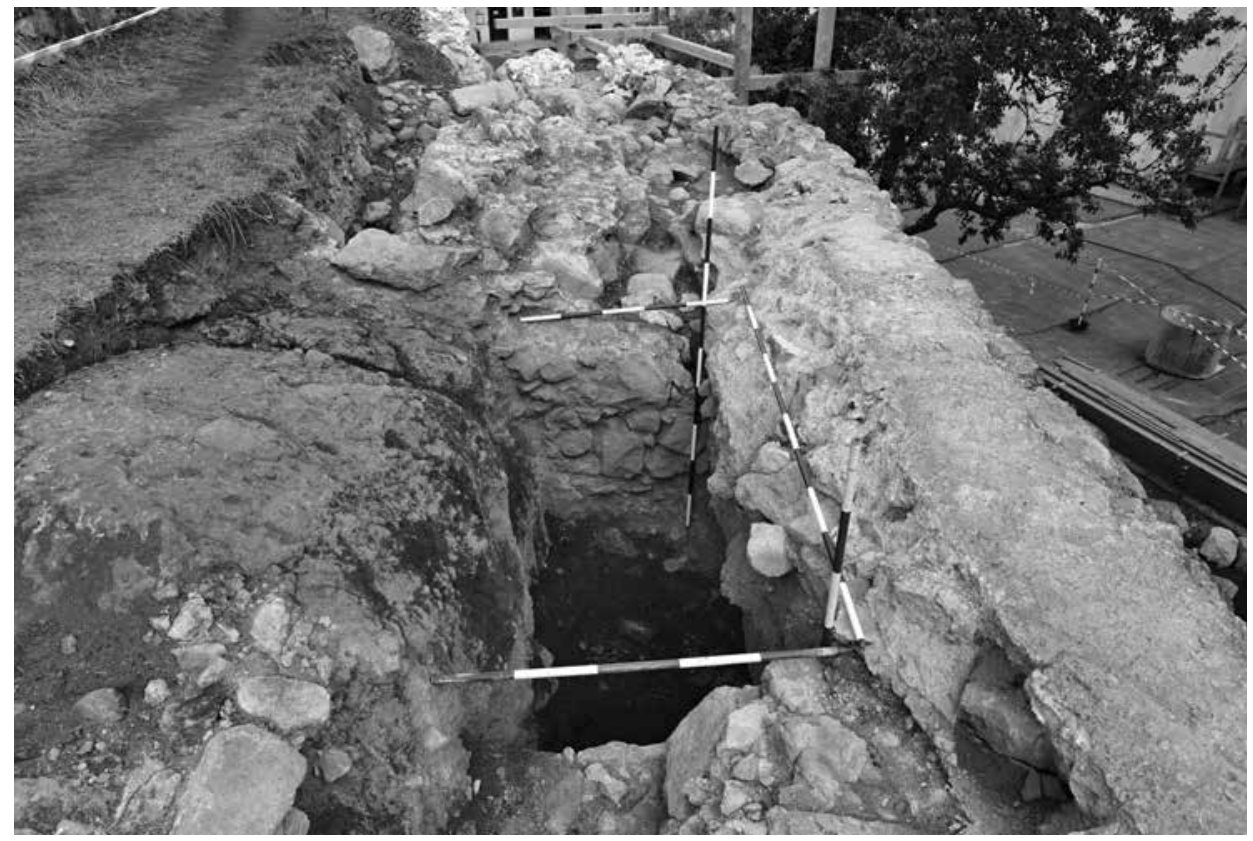

Obr. 11. Hrad Modrý Kameň, okr. Vel'ký Krtíš. Parkánová hradba s dovnútra otvorenou stavbou bránovej veže. Foto J. Beljak.

Abb. 11. Burg Blauenstein, Bezirk Vel'ký Krtíš. Zwingermauer mit nach innen offenem Torturmbau. Foto J. Beljak. 
s hrúbkou minimálne $2 \mathrm{~m}$ bola posunutá severným smerom pred čelo veže. K prestavanej hradbe sa z vnútornej strany priložila neznáma stavba, ktorá zrejme zaberala celú východnú čast' hradného jadra. Do neskorého stredoveku môžeme zrejme datovat' aj vybudovanie západného krídla obytných budov (obr. 6:6, 12). Zistená bola čast' zaklenutého spodného podlažia pristavaného k vnútornému lícu obvodovej hradby. Z jej vyššieho podlažia sa vo vnútornom líci západnej hradby zachovali zvyšky pece.

\section{Del'ba hradu v roku 1527 a protiosmanské opevnenie}

Strategický význam hradu pravdepodobne opät’ stúpol po bitke pri Moháči. Počas jarných mesiacov v roku 1527 si synovia nebohého Františka Balassu - Farkas (Wolfgangus), František ml. a Imrich s d’alšími nemenovanými (maloletými) bratmi rozdelili hrad a panstvo Modrý Kameň na polovicu so svojím bratrancom Jánom, synom nebohého Mikuláša. Opis hradu vtedy spomína pivnicu pri kamennej veži a tri drevené domy nad uvedenou pivnicou. Nachádzali sa v nich izba, pekáreň a komora. Pred týmito drevenými domami bola malá komora a pri veži stáli aj opustené kamenné domy. Predmetom del'by sa d’alej stala vel'ká izba, nazývaná palota, a dve drevené komory nad kaplnkou (supra scilicet capellam). Listina napokon spomína aj studňu (fons), nádvorie a dolný hrad, nazývaný parkan. ${ }^{1}$ Môžeme predpokladat', že dokument zaznamenáva podobu neskorostredovekého hradu ešte pred výraznými úpravami. Nepochybná je však len identifikácia valcovej veže. V prípade d’alších budov spomínaných v popise je pravdepodobné, že ide o obytné krídla priliehajúce k veži na západnej a severovýchodnej strane. Od nasledujúceho desat'ročia už máme doložený trvalejší pobyt Balassovcov na Modrom Kameni, kde zároveň sídlil aj ich modrokamenský kastelán (Matulay 1980, 432, 439, 442, č. 1429, 1456, 1468).

Osmanské ohrozenie viedlo Balassovcov k opevňovaniu Modrého Kameňa a zvlášt' k dobudovaniu predsunutej obrany v priestore dolného hradu. Podobu, akú hrad nadobudol počas týchto úprav, zachytávajú schematické kresby Modrého Kameňa (Khekv) od talianskych stavitel'ov Natale Angieliniho a jeho syna Paola Angieliniho približne z rokov 1572-1575 na mapách okolia banských miest (Pálffy 2011, 56-58, príloha obr. VIII a IX). Znázorňujú vyvýšený horný hrad s dominantnou vežou, opevnený vonkajšou obrannou líniou s tromi zretel’nými nárožnými bastiónmi. Hoci zobrazenie hradu na mape korešponduje s výsledkami výskumu, otázna je jeho hodnovernost'. Zatial' čo hrady a mestá v západnej časti mapy sú zakreslené v podobe verných miniatúr, vo východnej časti vrátane Modrého Kameňa sú zakreslené v rovnakej podobe.

\section{Zápas o hrad až po jeho prinavrátenie Balassovcom}

V júli roku 1575 po niekol'kých dňoch obliehania dobylo Modrý Kameň osmanské vojsko. Obliehaniu údajne predchádzal konflikt medzi zajatými Turkami (Osmanmi) v hradnom väzení a majitel’om hradu Jánom Balassom. Podl’a dobovej správy bola horná čast' hradu na nároží, kde sa nachádzala spálňa Jána Balassu, poškodená iba málo, lebo z horného hradu obrancovia strielali z pušiek a z dolnej časti hradu hádzali na útočníkov kamene. ${ }^{2}$ Piesňová tradícia nás informuje, že osmanské delá zničili baštu (aby múry obmekčili, krásnou baštu jsou lámali) a osmanské vojsko následne obsadilo hrad (Brtáň 1978, 110-111). Naopak, podl'a správy neskoršieho kronikára Mikuláša Istvánffyho bol hrad opevnený slabým múrom (debili muro extructa) a po pal'be z diel sa zmenil na ruinu (Isthvanfi 1622, 545-546, kniha XXV; Horváth 1972, 42-43).

Balassovci a okolití uhorskí vojenskí velitelia sa opakovane pokúšali hrad vydobyt', pričom najvýraznejšie sa na stavbe hradu prejavil útok na jeseň v roku 1588. Počas obliehania bolo vypálené predhradie aj hradné jadro. Citadela bola v tom čase opevnená parkánmi, plotom a baštami. Osmanská posádka sa ubránila v kamennej veži. K prinavráteniu Modrého Kameňa došlo preto až v roku 1593.Vojsko cisárskeho velitel'a Mikuláša Pálffyho vtedy obsadilo Fil’akovo, pričom osmanské posádky následne vyprázdnili okolité pevnosti. Modrý Kameň mali pri

1 Zachovaný latinský odpis z 19. storočia MNL, P 1815, Balassa cs. lt., 3. csomó, 8. tétel, fol. 16r.

2 ŠA BB p. AK, MMK, tomus 1, fons 26, fasc. 6, no. 970. 


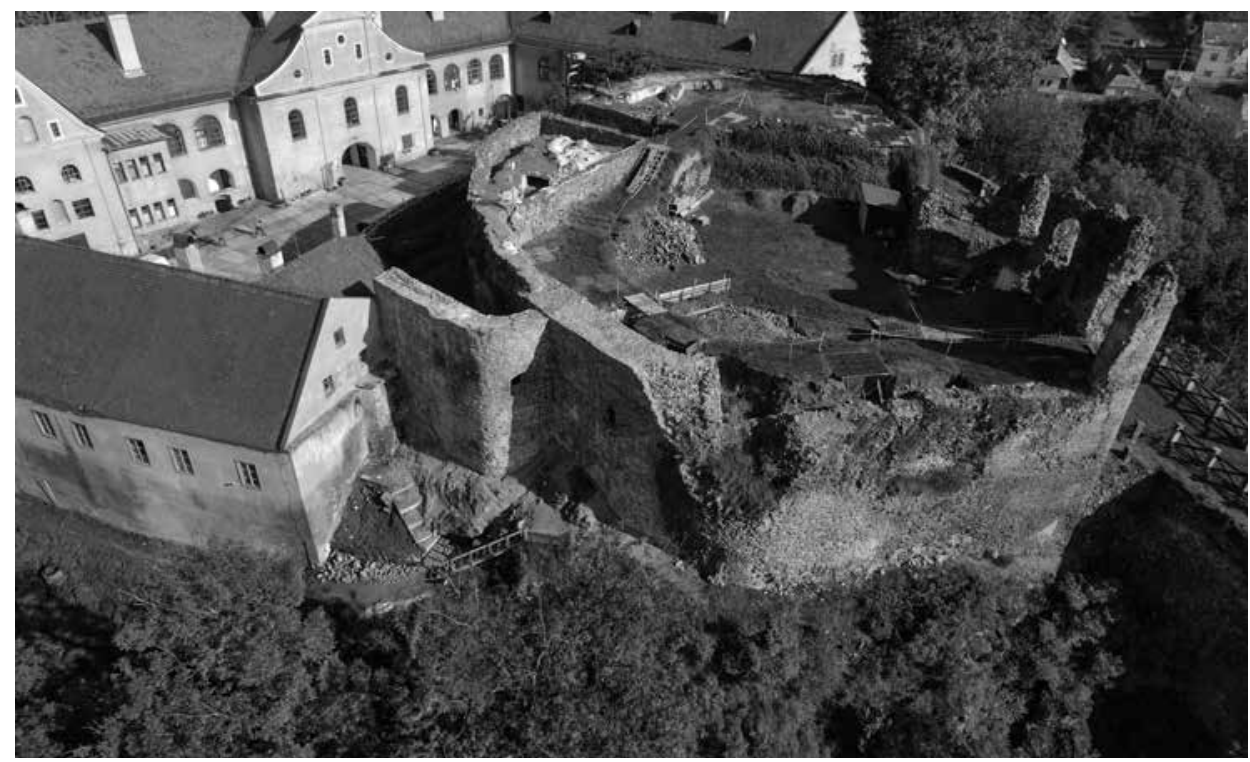

Obr. 12. Hrad Modrý Kameň, okr. Vel'ký Krtíš. Západná línia opevnenia hradného jadra s výskumom odkrytou architektúrou západného a juhozápadného krídla paláca v roku 2015. Foto J. Ornth.

Abb. 12. Burg Blauenstein, Bezirk Vel'ký Krtíš. Westflucht der Kernburgbefestigung mit bei der Grabung freigelegter Architektur des West- und Südwestflügels des Palas im Jahr 2015. Foto J. Ornth.

ústupe vyhodit' do povetria (Takáts-Eckhart-Szekfü 1915, 441-442, č. 387; Matunák 1928, 391, 397; 1983, 204-206; Plaček-Bóna 2007, 208). Túto udalost' pripomína aj mapa chronológie bojov medzi krest’anmi a Turkami v Uhorsku v rokoch 1593-1598, vytlačená v Augsburgu v roku 1598. Pri siluete Modrého Kameňa (Blobenstain, v legende ako Blawenstein) dielo zobrazuje silnú explóziu a požiar (Meuer 1992, 22). Poškodený hrad vyžadoval výrazné opravy, obnova však neprebiehala v krátkom časovom horizonte.

V roku 1605 počas protihabsburského povstania Štefana Bocskaya hrad obsadilo jeho vojsko pod velením Františka Rédeia, ktorý Modrý Kameň zveril svojmu zástupcovi Gregorovi Németimu. Opis hradu vtedy uvádza, že na kamennom hrade sa nachádza jedna temnica. Ešte v čase, ked' Fil'akovo ovládali Turci, bola obliehaná brána a odvtedy na Modrom Kameni nikto nič nestaval, ale tamojší kapitán teraz stavia. ${ }^{3}$ Po utíchnutí povstania hrad opät' nadobudli Balassovci a pristúpili k výraznejším stavebným úpravám. Žigmund Balassa v januári 1610 oznámil banským mestám, že jeho dedičné hrady Modrý Kameň a Divín boli z Božej vôle vydobyté od Turkov. Do súčasnosti sú spustošené v ruinách a terajší král' (Matej II. Habsburský) mu ich ráčil vrátit. Žigmund Balassa ich mal v úmysle opevnit' baštami tak, ako sú opevnené banské mestá. Žiadal preto mestá o pomoc pri obnove a oprave svojich hradov. ${ }^{4}$ Pravdepodobne išlo o poskytnutie remeselníkov a stavitelov, aj ked', ako uvádzame nižšie, takáto výpomoc nebola bezproblémová.

\section{Del'ba hradu v roku 1625}

Z roku 1625 sa zachoval pozoruhodný prameň o topografii hradu. Modrý Kameň si vtedy rozdelili synovia Žigmunda Balassu - Šimon, Ondrej, František, Ján a Ladislav. Opis najprv

3 MNL, E 156, UetC, fasc. 11, no. 49, pag. 59.

4 ŠA BB, MMBB, fasc. 240, num. 37. 
bez presnej lokalizácie spomína hornú bránu, baštu pod zbrojnicou (Czeythaz), kastelánov dom, domy drábov, pracháreň, pivovar (serfozo haz), brány, nádvoria, studňu (kuth), temnicu a uličku pomedzi bránu. Následne sa dozvedáme, že „na dolnom hrade nikto nikdy nestaval kamenné stavby, také, ktoré by boli na prekážku hornému hradu“.

Na strednom hrade vedla brány boli nové domy a pod nimi nad hornou bránou s pavlačou, resp. ochodzou (tornacz), začínal od brány na dolnom hrade kamenný múr. K hornej bráne zároveň patrili dve pivnice. Na hornom hrade sa nachádzala palota (vel'ká sieň) a pri nej pitvor (predsieň) so schodmi. Vedl'a stál vnútorný dom, nad ním komora a pod domami zaklenutá miestnost'. Na dolnom hrade sa nachádzala zaklenutá pivnica, ako aj nová maštal' a vedl'a nej bašta. Dom panej, pri ňom dom dievčat s komorou a pod ňou zaklenutá miestnost' zrejme susedili s horným nádvorím. Del'ba napokon spomína časti s baštou na mieste starej brány $(O \mathrm{kapu})$ na dolnom hrade, s ochodzou nad novou bránou (Uy kapu), od zvonice po kaplnku spolu s kamenným múrom a tureckým kúpel’om (török fürdöház). Opis sa znovu vracia na horný hrad, ked' spomína vežu a kaplnku. Na strednom hrade ešte uvádza školu (iskolahaz) a medzi objektmi s otáznou lokalizáciou menuje starú palotu. ${ }^{5}$ Okrem opisu, polohy a funkcií jednotlivých častí hradu spomína del'ba predovšetkým základné rozdelenie hradu Modrý Kameň na tri časti: dolný, stredný a horný hrad. Z hl'adiska kultúrnych dejín mohol hrad pôsobit' kontrastne. Popri kaplnke, škole a dome panej i dievčat (tzv. fraucimer), ktoré vystihovali nové požiadavky súdobej šlachtickej kultúry (Paravicini 2000, 17-21; Duchoňová 2013, 202-205), nachádzame zmienku aj o tureckom kúpeli. Doterajšie bádanie takýto typ hygienického zariadenia na Modrom Kameni neeviduje. Rozšírenie tureckých kúpel'ov spája najmä s trvalejšou prítomnostou osmanskej kultúry na okupovaných územiach. Na druhej strane, turecké kúpele sú doložené napr. v ned’alekých Sečanoch (Szécsény). Nakol'ko kúpele v šlachtickom prostredí všeobecne plnili aj dôležitú spoločenskú a reprezentačnú funkciu (Sudár 2004, 399-432; Lengyelová 2016, 48-50), ich prítomnost' na Modrom Kameni neprekvapuje. Je však otázne, či mohlo íst' o pôvodné turecké kúpele z rokov 1575-1593, alebo o mladšiu stavbu, inšpirovanú osmanskými vzormi.

Pokračujúca obnova a dostavba hradu sa nezaobišla bez komplikácí́. František Balassa, syn nebohého Žigmunda, písal z Modrého Kameňa v roku 1638 opakovane zástupcom mesta Banská Bystrica. Požadoval, aby mesto zabezpečilo vyslanie kamenára, ktorý mal zhotovit' dielo podl'a dohody. Na hrad sa však nedostavil. František Balassa preto následne pohrozil, že dá na svojom panstve zadržat' cestujúcich obyvatel'ov Banskej Bystrice, ak remeselník nedokončí dielo. Ťǎkosti vznikli aj s vyplatením remeselníka. Balassa preto slúbil, že kamenárovi Jakubovi vyplatí mzdu. Zástupcom mesta zároveň pripomenul, že ak kamenára k nemu nepošlú, bude to na jeho vlastnú škodu. S priebehom prác však ani potom František Balassa nebol spokojný. Aj v roku 1639 preto informoval zástupcov Banskej Bystrice o obhliadke diela, ktoré ešte stále nebolo dokončené podl'a dohody. ${ }^{6}$ Tieto peripetie naznačujú, že stavebné aktivity na hradoch okrem problémov s financovaním mohol zabrzdit' aj nedostatok kvalifikovaných robotníkov. V tomto kontexte možno zároveň uvažovat' o komplexnej (i ked' azda nie urýchlenej) výstavbe kaštiel'a v susedstve staršieho hradného jadra na Modrom Kameni, pričom tieto dva areály a ich zariadenie v dosial' známych písomných prameňoch od polovice 17. storočia (Füreder 2007, 129, 138-140) ešte nevieme jednoznačne rozlišovat'.

\section{Podoba renesančného hradu na základe výskumov}

Významným medzníkom v dejinách hradu boli nepochybne jeho dobývania v rokoch 1575 , 1588 a predovšetkým opätovné získanie a pravdepodobné poškodenie hradu v roku 1593 . Po roku 1610, ked’ sa Modrý Kameň, ktorý mal byt’ v ruinách, vrátil do rúk Žigmunda Balassu, bola zrejme realizovaná rozsiahla rekonštrukcia rozrumeného hradu. Jej rozsah overil predovšetkým výskum juhovýchodného paláca (obr. 6:4) v roku 1998. Okrem zaklenutia spodného podlažia

5 Mad’arský originál a odpis z 19. storočia MNL, P 1815, Balassa cs. It., 3. tétel, Kékkői uradalom 1585-1826, 17.-18. század + év nélkül, fol. $79 \mathrm{r}-81 \mathrm{r}, 76 \mathrm{r}-\mathrm{v}$.

6 ŠA BB, MMBB, fasc. 888 , no. 35 , fasc. 872 , no. 17 , fasc. 878 , no. 63 , fasc. 394 , no. 41 


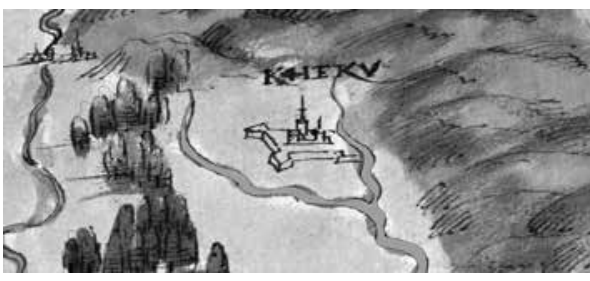

Obr. 13. Hrad Modrý Kameň, okr. Vel'ký Krtíš. Vyobrazenie hradu na mape okolia banských miest od Natale a Paola Angieliniovcov z rokov 1572-1575. Podl'a Pálffy 2011 prekreslil A. Loydl.

Abb. 13. Burg Blauenstein, Bezirk Vel'ký Krtíš. Darstellung der Burg auf einer Karte in der Umgebung von Bergbaustätten von Natale und Paolo Angielini aus den Jahren 1572-1575. Nach Pálffy 2011, Umzeichnung A. Loydl.

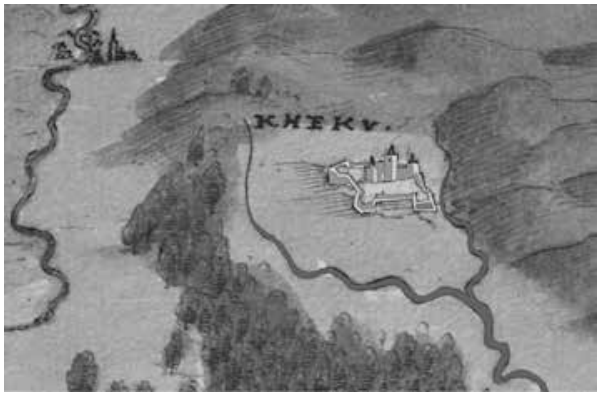

Obr. 14. Hrad Modrý Kameň, okr. Vel'ký Krtíš. Vyobrazenie hradu na mape okolia banských miest od Natale a Paola Angieliniovcov z rokov 1572-1575. Podl'a Pálffy 2011 prekreslil A. Loydl.

Abb. 14. Burg Blauenstein, Bezirk Vel'ký Krtíš. Darstellung der Burg auf einer Karte in der Umgebung von Bergbaustätten von von Natale und Paolo Angielini aus den Jahren 1572-1575. Nach Pálffy 2011, Umzeichnung A. Loydl. tehlovými klenbami boli kompletne prestavané poškodené obvodové múry druhého, tretieho a štvrtého podlažia. Palác bol do exteriéru otvorený rozmernými oknami, z vnútorného vybavenia sa zachoval zvyšok krbu alebo pece s komínom. Nad vstupom do horného hradu (obr. 6:3) vznikla chodbička $\mathrm{v}$ hrúbke muriva, slúžiaca na obranu vstupu. Spomenuté datovanie obnovy hradu potvrdil nález troch tvaroslovných článkov z konca 15 . až začiatku 16. storočia, použitých sekundárne ako stavebný materiál vo východnom nároží. Druhým nálezom potvrdzujúcim znovu výstavbu paláca začiatkom 17. storočia bola stratigrafická situácia vrstiev podláh na korune severozápadného múru paláca nad vstupom. Tu boli odkryté celkovo tri vrstvy podláh druhého podlažia a s nimi korešpondujúce interiérové omietky. Podlahy pozostávali zo zásypu na valenej klenbe nižšieho podlažia a povrchovej vrstvy tvorenej keramickými dlaždicami alebo hladenou maltou. Zásyp druhej vrstvy obsahoval zlomok bielo engobovanej kachlice z rozobratej kachl'ovej pece z prvej polovice 16. storočia.

V prípade d’alších renesančných úprav už nemáme jednoznačné doklady o ich presnejšom datovaní. Je vel'mi pravdepodobné, že so získaním hradu v roku 1593 a následnou rekonštrukciou je možné spájat' zánik stredovekej veže. Jej nadzemná hmota bola zbúraná tak, že ostalo zachované len spodné podlažie. $\mathrm{Na}$ ňom vznikla mladšia stavba s odlišným pôdorysom (obr. 6:7), ktorá mala vnútorné líca vybudované z tehál. Podobne do tohto obdobia môže patrit' zaklenutie juhozápadného paláca (obr. 6:5) tehlovými klenbami a rozsiahla obnova parkánu spojená s vybudovaním novej parkánovej hradby.

Do značnej miery je dnes neprebádanou otázkou podoba vonkajšieho opevnenia hradu, ktorého existenciu je možné predpokladat' na mieste dnešného barokového kaštiela (obr. 15). Potvrdili to aj výsledky aktuálneho architektonicko-historického výskumu fasád východného krídla. V jeho hmote bola zistená pôvodná hradba s hranolovou nárožnou baštou. Datovanie vzniku tohto opevnenia je zatial' otázne. Pravdepodobná sa javí jeho výstavba v rámci obnovy hradu na začiatku 17. storočia. Nie je možné vylúčit' ani skoršie datovanie už okolo polovice 16. storočia. Naznačovalo by to vyobrazenie Modrého Kameňa na mape z doby okolo roku 1575 (obr. 14). Skica hradu sa podobne ako v prípade d’alších hradov (napr. Čabrad', Nitra, Levice) javí ako pomerne verná. Na mape je zobrazené jadro hradu s dominantnou vežou a predhradím s trojicou nárožných bastiónov. Problémom je, že identické vyobrazenie je použité aj pri zakreslení d’alších hradov vo východnej časti mapy.

Ďalšie adaptácie obytných budov v priebehu 17. storočia boli spojené s rozšírením staršej budovy na severovýchodnej strane jadra. Okrem zosilnenia obvodovej stavby bol interiér rozdelený priečkou. V oboch odkrytých miestnostiach boli zistené zvyšky vykurovacích zariadení v podobe pece, resp. komínového telesa. Čiastkové úpravy spojené s vybudovaním nového schodiska boli zistené v západnom krídle. Prestavby hradu v priebehu 17. storočia sformovali 


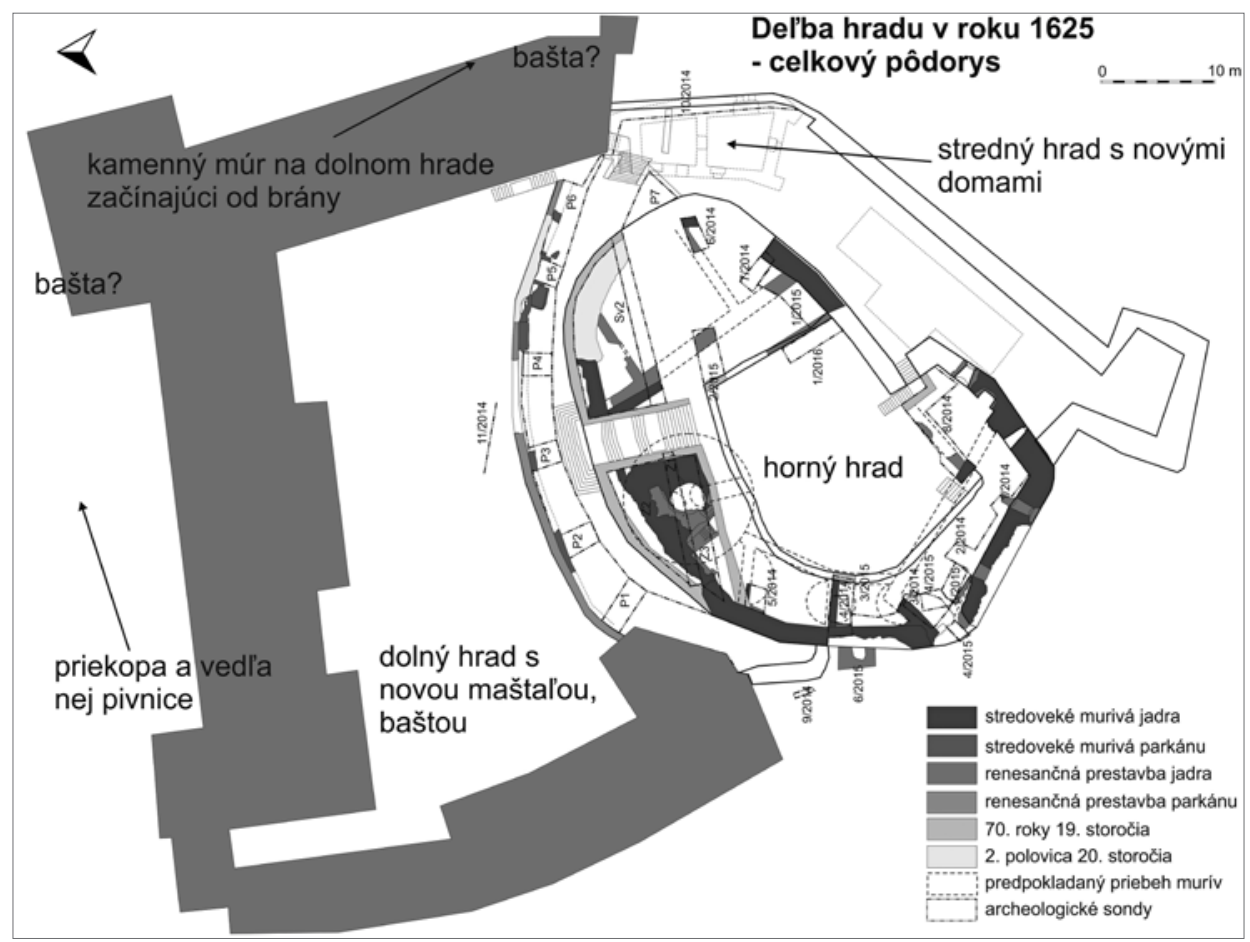

Obr. 15. Hrad Modrý Kameň, okr. Vel'ký Krtíšs. Celkový pôdorys hradu s rekonštrukciou zástavby horného hradu a naznačením opevnenia, ktoré boli zistené v rámci barokového kaštiel’a (šrafovane predpokladaný priebeh hradby), s pokusom o vyznačenie objektov spomenutých v del’be hradu z roku 1625. A - horný hrad, B - stredný hrad, C - dolný hrad, 1 - veža, 2 -stará palota, 3 - brána stredného hradu, 4 - budovy pri bráne stredného hradu, 5 - bašta v dolnom hrade, 6 - nová brána v dolnom hrade. Vyhotovili M. Šimkovic, J. Beljak, A. Loydl.

Abb. 15. Burg Blauenstein, Bezirk Vel'ký Krtíš. Gesamtgrundriss der Burg mit rekonstruierter Bebauung der oberen Burg und skizzierter Befestigung, die im Rahmen des Barockschlosses entdeckt wurde (schraffierter mutmaßlicher Verlauf der Wehrmauer) sowie Versuch, die in der Beschreibung der Burgaufteilung von 1625 erwähnten Objekte zu kennzeichnen. A - obere Burg, B - Mittelburg, C - untere Burg, 1 - Turm, 2 - alter Saal, 3 - Tor der Mittelburg, 4 - Gebäude am Tor der Mittelburg, 5 - Bastei in der unteren Burg, 6 - neues Tor in der unteren Burg. Erstellt von M. Šimkovic, J. Beljak, A. Loydl.

zástavbu obytných krídel, ktorá bola rozložená okolo ústredného nádvoria po celom obvode opevnenia.

\section{Hnutel’né archeologické nálezy}

Najstaršie stredoveké keramické nálezy z výskumu na hrade Modrý Kameň môžeme datovat' do záveru 13. storočia, resp. na začiatok 14. storočia. Do nasledujúceho obdobia 14.-15. storočia patria takmer výlučne fragmenty bielej keramiky z novohradsko-gemerského regiónu (obr. 16). Tieto nálezy sú málo početné. Súvisí to aj s metódou archeologického výskumu zameraného na sanáciu torzálnej architektúry hradu. Sondami sme skúmali predovšetkým sekundárne zásypy z 19. storočia a zriedkavo sme sa dostali pod híbku jeden meter. Keramické nálezy zo 16. storočia netvoria príliš početnú skupinu medzi nálezmi z výskumu na Modrom Kameni. Reprezentujú ich hrnce zdobené zelenou alebo žltou glazúrou bez podkladových engob, príp. bez glazúry. V roku 2016 sa v renesančnej klenbe pod severovýchodnou terasou podarilo objavit' tri kompletné exempláre hrncov zo záveru 16. storočia (obr. 17:2, 3). Vyrobené boli z bielych ílov. Mal'ovaná výzdoba červenou engóbou sa vyskytuje na hrncoch od druhej polovice alebo od záveru 16. storočia. V modrokamenskom súbore sú zastúpené aj glazované a neglazované 

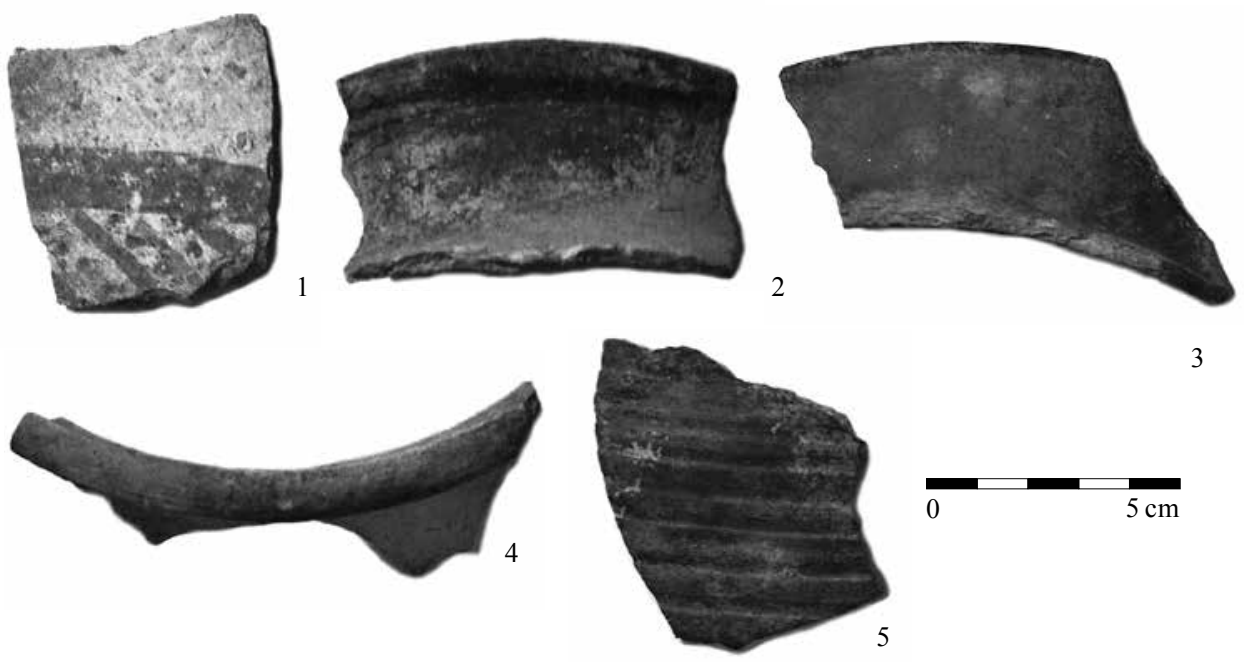

Obr. 16. Hrad Modrý Kameň, okr. Vel'ký Krtíš. Výber keramických fragmentov z obdobia vrcholného stredoveku. Foto M. Holeščák.

Abb. 16. Burg Blauenstein, Bezirk Vel'ký Krtís. Auswahl an Keramikfragmenten aus dem Hochmittelalter. Foto M. Holeščák.

džbány. Neglazované džbány sa obyčajne zdobili červenými pásmi s rytou vlnovkou v hornej časti nádoby. Pre glazované exempláre bolo pre toto obdobie typické spoločné používanie dvoch farieb glazúr, predovšetkým zelenej a žltej. Medzi keramickými nálezmi zo 16. storočia sú menej početne zastúpené aj tvary ako trojnožka, pokrievka a poháre. V súbore keramiky z Modrého Kameňa sa vyskytli tiež fragmenty luxusných nádob s rezano-glazovanou výzdobou zo 16. storočia. Objavili sme aj fragment renesančnej kachlice zdobenej rozetovým ornamentom z prvej polovice 16. storočia.

Najpočetnejšia skupina keramických nálezov z výskumu na hrade Modrý Kameň pochádza zo 17. storočia. Najväčšiu čast’ predstavujú hrnce, väčšinou zdobené červenou engobou na vonkajšej strane a v nej aplikovanou rytou výzdobou. Medzi nálezmi hrncov sa vyskytujú aj neglazované príklady vyrobené z bielej a červenej hliny. Ďalším početným tvarom sú taniere a misy z bielej hliny s výzdobou rytou do engóby pod glazúrou a s technikou kukučkovania. Pri všetkých tanieroch zdobených kukučkovaním sa používali transparentné glazúry.

V súbore keramiky zo 17. storočia sa vyskytuje niekol'ko druhov džbánov vyrobených z ílov bielej farby. Väčšina z nich mala glazovaný povrch žltej, zelenej alebo zriedkavejšie hnedej farby. Džbány s úzkym hrdlom mali aj cedidlo na úrovni pripojenia ucha. Máme potvrdené tiež fragmenty menej populárnych druhov nádob, ktoré v tomto období reprezentujú napr. trojnožky vyrobené z bielej hliny a zdobené zelenou alebo žltou glazúrou.

Na hrade sa našli aj glazované fajky a nezdobené miskovité kachlice. Potvrdilo sa tiež niekol'ko exemplárov pokrievok. Od prelomu 16. a 17. storočia sa objavujú i tmavošedé nádoby nových tvarov s leštenou výzdobou na povrchu. Unikátnym nálezom z Modrého Kameňa je fragment čínskeho porcelánu alebo iznickej fajansy (obr. 18:12). Na hrad sa mohol dostat' ešte počas osmanskej nadvlády v 16. storočí, ale zrejme sa používal až do 17. storočia. Mimoriadnym nálezom je aj fragment neglazovaného hrnca s mal'ovanou výzdobou, ktorý má na vonkajšej strane umiestnený nadpis „BK“ (obr. 19:3). Mohol poukazovat' na majitel'a nádoby alebo na jej použitie.

Menej početná je výskumom získaná keramika z 18. storočia (Beljak-Mordovin-Šimkovic-Kaličiaková 2016, 282-285). Tvoria ju nádoby vysokých tvarov (hrnce, trojnožky a džbány). 

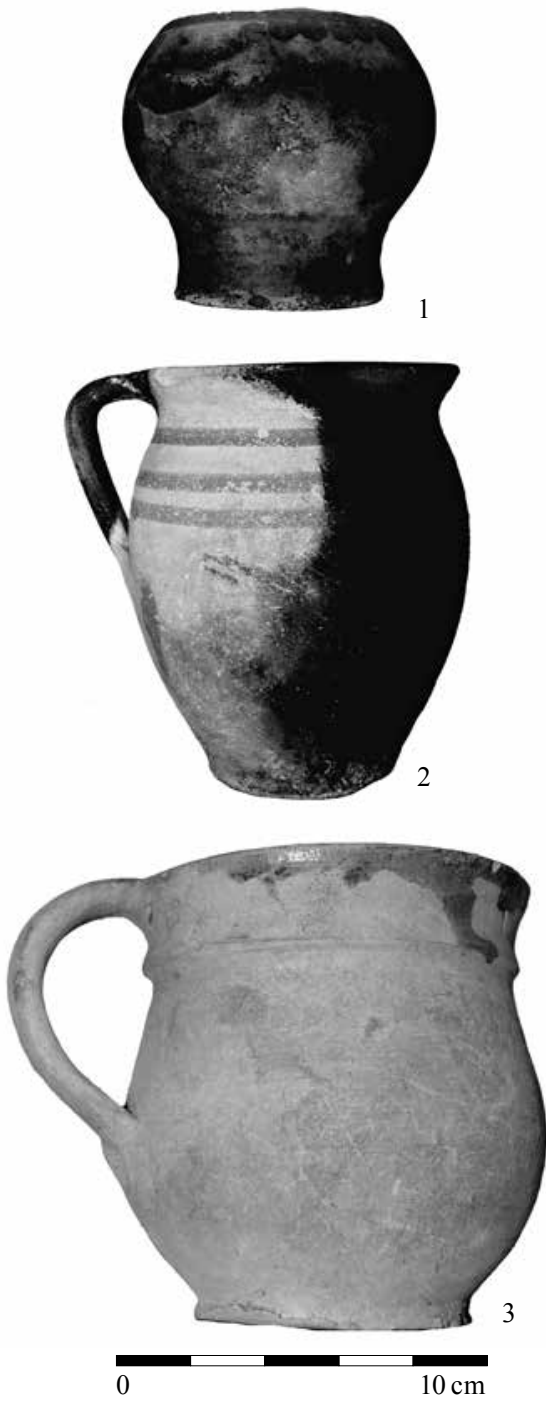

Obr. 17. Hrad Modrý Kameň, okr. Vel'ký Krtíš. Kompletne zachované hrnce a torzo pohára zo záveru 16. storočia, objavené v sonde 1/2016. Foto $Z$. Kaličiaková.

Abb. 17. Burg Blauenstein, Bezirk Vel'ký Krtíšs. In Sondierschnitt 1/2016 entdeckte komplett erhaltene Töpfe und Torso eines Bechers vom Ende des 16. Jahrhunderts. Foto Z. Kaličiaková. s čím korešpondujú aj najstaršie stredoveké keramické fragmenty získané archeologickým výskumom. Nepravidelný oválny pôdorys jadra s osami 46 a $32 \mathrm{~m}$ bol vymedzený hradbovým múrom, do ktorého bola na severnej strane zakomponovaná valcová, pravdepodobne obytná veža. Vstupná brána bola vybudovaná v zalomení hradby na juhovýchode. Tento predpoklad podporujú aj najstaršie stredoveké keramické fragmenty získané archeologickým výskumom. Výsledkom mladších stredovekých úprav je vznik paláca na juhozápadnej strane, z ktorého sa zachovali dve obvodové steny so zvyškami gotického okna a kozuba. V neskorom stredoveku boli vybudované aj d’alšie obytné stavby a severný parkán so vstupnou bránou. 

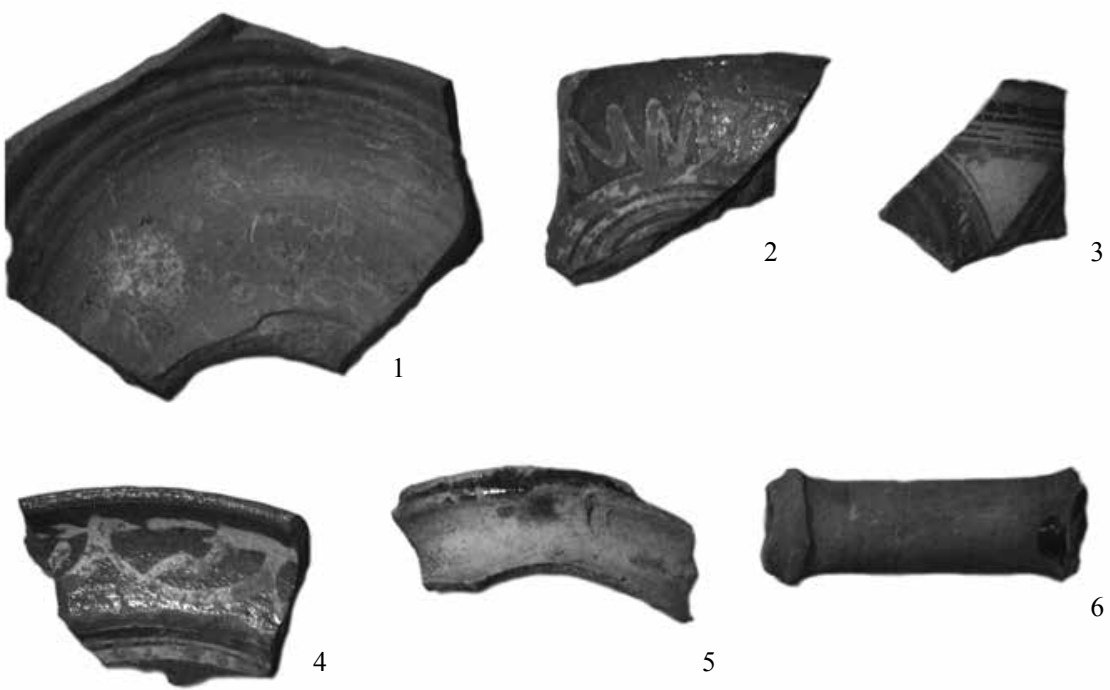

4

5
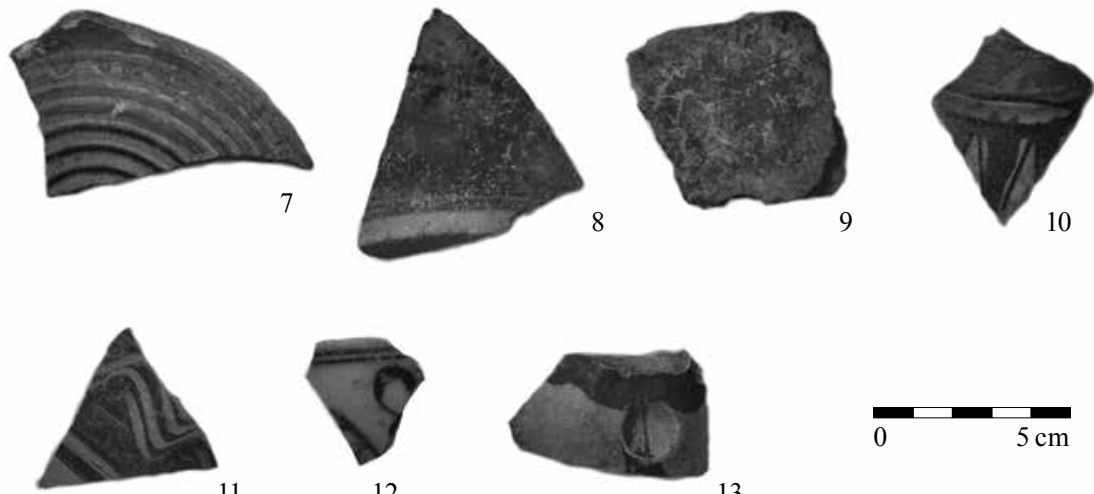

11

12

13

Obr. 18. Hrad Modrý Kameň, okr. Vel'ký Krtíš. Výber keramických fragmentov zo 17. storočia. Foto M. Holeščák.

Abb. 18. Burg Blauenstein, Bezirk Vel'ký Krtíš. Auswahl an Keramikfragmenten aus dem 17. Jahrhundert. Foto M. Holeščák.

K významnej renesančnej prestavbe hradu Modrý Kameň došlo v 17. storočí. V roku 1575 hrad obsadili Osmani, ktorí ho opustili až v roku 1593. Poškodený hrad začal od roku 1610 rekonštruovat’ Žigmund Balassa. Pri tejto rekonštrukcii boli obnovené palácové budovy hradného jadra a pravdepodobne vzniklo aj nové opevnenie predhradia. $Z$ tohto obdobia pochádza aj najviac hnutel’ných archeologických nálezov získaných výskumom v rokoch 2013-2016. O podobe hradu Modrý Kameň v tomto období nás informuje jeho podrobný opis datovaný do roku 1625. Podobne ako v prípade stručnejšieho opisu hradu z roku 1527, ani tento nám neumožňuje stotožnenie jednotlivých výskumom zistených budov. Z hl’adiska členenia hradného areálu predpokladáme, že termínom „horný hrad“ je označené jadro, pojem „stredný hrad“ sa vztahuje na parkán a „dolný hrad“ označuje predhradie v mieste dnešného kaštiel’a. Popis dokladá doteraz neznámu zástavbu (,„škola a nové domy“) v priestore parkánu. Lokalizovat’ je možné len hornú bránu, ktorá je zrejme totožná s dodnes zachovaným vstupom na východnej strane. Okrem objektov typických pre renesančný šl'achtický dvor (dom panej, fraucimer) sa na hrade stretávame aj s tureckým kúpel’om, ktorý na základe súčasných poznatkov nemožno lokalizovat'. 

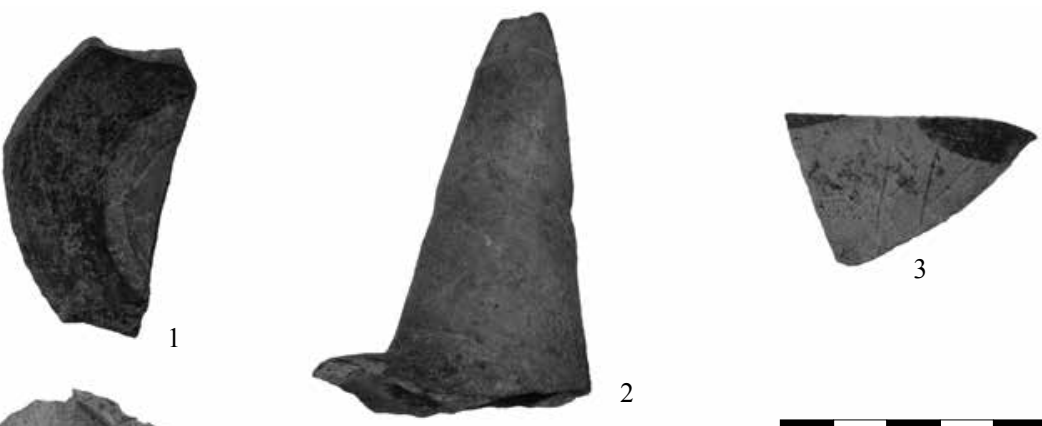

2
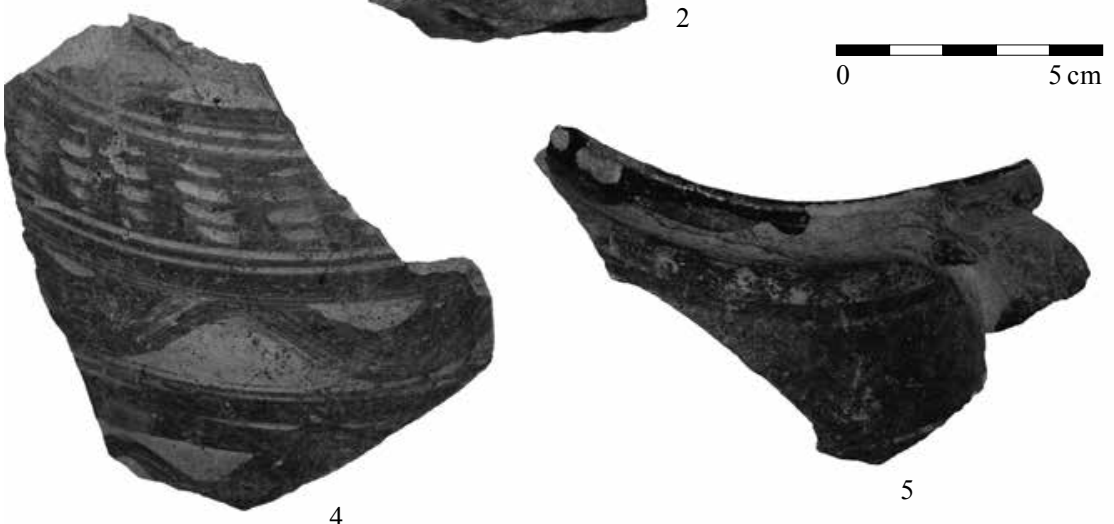

5

Obr. 19. Hrad Modrý Kameň, okr. Vel'ký Krtíš. Výber keramických fragmentov zo 17. storočia. Foto M. Holeščák. Abb. 19. Burg Blauenstein, Bezirk Vel'ký Krtíš. Auswahl an Keramikfragmenten aus dem 17. Jahrhundert. Foto M. Holeščák.

Pravdepodobne od konca 17. storočia hradné jadro postupne prestalo plnit' obytnú funkciu. V ovel’a menšej miere bola výskumom získaná keramika z 18. storočia. To by nasvedčovalo úprave severozápadnej a východnej terasy až v 70. rokoch 19. storočia, kedy bolo hradné jadro upravené do podoby parku. Rezidenčnú úlohu prevzal barokový kaštiel' vybudovaný v severnom podhradí v prvej polovici 18. storočia Gabrielom Balassom. Jeho pôdorys spolu s pôdorysom hradného jadra pred parkovou úpravou zachytáva Karol Bergh v roku 1862, resp. 1866 (obr. 3). Naopak, v roku 1889 zaznamenal pôdorys hradu s hradným jadrom už po parkovej úprave Jozef Könyöki.

Príspevok je publikovaný v rámci riešenia projektu Vedeckej grantovej agentúry Ministerstva školstva, vedy, výskumu a športu Slovenskej republiky a Slovenskej akadémie vied (VEGA) číslo 1/0208/15: Človek a hory v priebehu času - od pravekých hradísk k stredovekým hradom, Centra excelentnosti SAV: Hrady na Slovensku. Interdisciplinárny prierezový pohl’ad na fenomén hradov a VEGA 1/0095/17: Kríza a kolaps na pomedzí stredoveku a novoveku (sondy do problematiky v slovenskom kontexte).

\section{Pramene a literatúra}

ALBERTY, J.-SLOBODA, J., edd., 1989: Novohrad. Regionálna vlastivedná monografia 2/1. Dejiny. Martin.

Balassa cs. 1t.: Magyar Nemzeti Levéltár - Országos Levéltára Budapest, fond Balassa család levéltára. BEL, M., 1742: Notitia Hungariae novae historico-geographica. Tomus quartus. Viennae.

BELJAK, J.-DEBNÁR, P.-KALIČIAKOVÁ, Z.-ŠIMKOVIC, M., 2014: NKP Hrad Modrý Kameň. Výskumná dokumentácia z archeologického výskumu č. 185961, ulož. v AÚ SAV, Nitra. 
BELJAK, J.-HOLEŠČÁK, M.-ŠIMKOVIC, M., 2013: NKP Hrad Modrý Kameň. Výskumná dokumentácia z archeologického výskumu č. 18397, ulož. v AÚ SAV, Nitra.

BELJAK, J.-HOLEŠČÁK, M.-KALIČIAKOVÁ, Z., 2015: NKP Hrad Modrý Kameň. Výskumná dokumentácia z archeologického výskumu č. 18954, ulož. v AÚ SAV, Nitra.

BELJAK, J.-KALIČIAKOVÁ, Z., 2016: NKP Hrad Modrý Kameň. Výskumná dokumentácia z archeologického výskumu č. 19087, ulož. v AÚ SAV, Nitra.

BELJAK, J.-MALINIAK, P.-MORDOVIN, M.-ŠIMKOVIC, M., 2016: Výskum tretej (pôvodne hornej) brány hradu Čabrad' v rokoch 2013-2015 - Die Grabung am dritten (ursprünglich oberen) Tor der Burg Čabrad' von 2013-2015, AH 41, 99-132.

BELJAK, J.-MORDOVIN, M.-KALIČIAKOVÁ, Z.-ŠIMKOVIC, M., 2016: Archeologický výskum na hrade Modrý Kameň v rokoch 2013-2015. In: Valentín Balaša a jeho doba - historické súvislosti. Zborník z II. medzinárodnej konferencie Modrý Kameň, september 2014 (Ferencová, H.-Antolová, E., edd.), 277-293. Modrý Kameň.

BOROVSZKY, S., ed., 1911: Magyarország vármegyéi és városai. Nógrád vármegye. Budapest.

BRTÁŇ, R., ed., 1978: Historické spevy a piesne. Bratislava.

DUCHOŇOVÁ, D., 2013: Palatín Mikuláš Esterházy a jeho dvor. Spoločnost', normy, rituály každodennosti. Bratislava.

FEKETE NAGY, A.-BORSA, I., edd., 1990: A Balassa család levéltára 1193-1526. Budapest.

FÜGEDI, E., 1977: Vár és társadalom a 13.-14. századi Magyarországon. Budapest.

FÜREDER, B., 2007: A Balassi család étkező asztalain használt esz közöt a XVII. században, Lymbus 2007, 127-143.

HANKO, J., 2012: Balašovci z Ďarmôt a Modrého Kameňa. Krupina.

HORVÁTH, P., 1972: Rabovali Turci... Výber z kroník a listov zo 16. a 17. storočia. Bratislava.

HORVÁTH, R., 2013: „Gradus ad Parnassum“. Ďarmotskí Balašovci v neskorom stredoveku. In: Rod Balašovcov v 13. až 16. storočí. Zborník z medzinárodnej konferencie (Ferencová, H.-Antolová, E., edd.), 38-46. Modrý Kameň.

ISTHVANFI, N., 1622: Nicolai Isthvanfi Pannoni historiarum de rebus ungaricis libri XXXIV. Coloniae Agrippinae.

LENGYELOVÁ, T., 2016: Život na šlachtickom dvore. Bratislava.

MATULAY, C., ed., 1980: Mesto Banská Bystrica. Katalóg administratívnych a súdnych písomností (1020) 1255-1536 II. Bratislava.

MATUNÁK, M., 1928: Z dejín slobodného a hlavného banského mesta Kremnice. Kremnica.

- 1983: Život a boje na slovensko-tureckom pohraničí. Bratislava.

MEUER, P. H., 1992: Eine Kriegskarte Ungarns von Dominicus Custos (Augsburg 1598), Cartographica Hungarica 1, 22-24.

MMBB: Štátny archív v Banskej Bystrici, fond Magistrát mesta Banská Bystrica.

MMK: Štátny archív v Banskej Bystrici, pracovisko Archív Kremnica, fond Magistrát mesta Kremnica.

MNL DF: Magyar Nemzeti Levéltár - Országos Levéltára Budapest Budapest [Mad’arský národný archív Krajinský archív v Budapešti], fond Diplomatikai fényképgyüjtemény.

MNL DL: Magyar Nemzeti Levéltár - Országos Levéltára Budapest Budapest [Mad’arský národný archív Krajinský archív v Budapešti], fond Diplomatikai levéltár.

PÁLFFY, G., 2011: Die Anfänge der Militärkartographie in der Habsburgermonarchie. A haditérképészet kezdetei a Habsburg Monarchiában. Budapest, s prílohou DVD.

PARAVICINI, W., 2000: Das Frauenzimmer. Die Frau bei Fofe in Spätmittelalter und Früher Neuzeit. In: Das Frauenzimmer. Die Frau bei Fofe in Spätmittelalter und früher Neuzeit (Hirschbiegel, J.-Paravicini, W., edd.), 13-25. Stuttgart.

PLAČEK, M.-BÓNA, M., 2007: Encyklopédia slovenských hradov. Bratislava.

SITÁR, T., 2016: Kde ležali Osláre v Novohrade? Pokus o rekonštrukciu hraníc stredovekého sídla. In: Zborník zo stretnutia priatel’ov regionálnej histórie. II. ročník, 36-45. Hradište.

SUDÁR, B., 2004: Baths in Ottoman Hungary, Acta Orientalia Academiae Scientiarum Hungaricae 57, č. 4, 391-437.

ŠA BB p. AK: Štátny archív v Banskej Bystrici, pracovisko Archív Kremnica.

ŠIMKOVIC, M., 2000: Pamiatková úprava juhovýchodnej časti hradu Modrý Kameň - poznámky k metodike výskumu a úprav hradov. In: Metodológia obnovy kultúrneho dedičstva, 183. Bratislava.

- 2015: Hrad Modrý Kameň, architektonicko-historické vyhodnotenie murív odkrytých archeologickým výskumom v roku 2014, ulož. v KPÚ, Banská Bystrica.

TAKÁTS, S.-ECKHART, S.-SZEKFÜ, Gy., edd., 1915: A budai basák magyar nyelvű levelezése I. 15531589. Budapest. 
UetC: Magyar Nemzeti Levéltár - Országos Levéltára Budapest, fond Urbaria et conscriptiones.

VÁLINÉ POGÁNY, J., ed., 2000: Az örökség hagyományozása. Könyöki József műemlékfelmérései 18691890. Budapest.

\section{Zusammenfassung}

\section{Bauliche und funktionelle Veränderungen von Burg Blauenstein im 16. und 17. Jahrhundert}

Die in den Jahren 2013-2016 auf Burg Blauenstein durchgeführte archäologische Grabung und bauhistorische Untersuchung brachte neue Erkenntnisse über das Aussehen und die Entwicklung der Burg, die noch um die Ergebnisse einer Archivforschung ergänzt werden. Anhand der ersten schriftlichen Erwähnung der Burg im Jahr 1278 kann ihre Entstehung in die erste Hälfte des 13. Jahrhunderts datiert werden, was auch mit den ältesten mittelalterlichen Keramikfragmenten korrespondiert, die bei der archäologischen Grabung gefunden wurden. Der unregelmäßige ovale Grundriss der Kernburg, dessen Achsen sich auf 46 und $32 \mathrm{~m}$ belaufen, war von einer Wehrmauer umgrenzt, an deren Nordseite ein zylinderförmiger Turm hineinkomponiert wurde, bei dem es sich wahrscheinlich um einen Wohnturm handelte. Das Eingangstor wurde im Südosten in einen Wehrmauerknick eingebaut. Diese Annahme wird auch durch die ältesten mittelalterlichen Keramikfragmente gestützt, die bei der archäologischen Grabung gefunden wurden. Ergebnis von jüngeren mittelalterlichen Umbauten ist die Entstehung eines Palas auf südwestlicher Seite, von dem zwei Außenmauern mit Überresten eines gotischen Fensters und einer Feuerstelle erhalten geblieben sind. Im Spätmittelalter wurden noch weitere Wohnbauten errichtet sowie im Norden ein Zwinger angelegt, der mit einem Eingangstor versehen wurde.

$\mathrm{Zu}$ einem bedeutenderen renaissancezeitlichen Umbau von Burg Blauenstein ist es im 17. Jahrhundert gekommen. Im Jahr 1575 wurde die Burg von den Osmanen besetzt, die sie erst im Jahr 1593 wieder verließen. Ab 1610 begann Sigmund Balassa die beschädigte Burg wieder herzurichten. Bei diesem Wiederaufbau wurden die Palasgebäude der Burg erneuert, und wahrscheinlich entstand auch eine neue Befestigung der Vorburg. Aus dieser Zeit stammen auch die meisten in den Jahren 2013-2016 bei der Grabung entdeckten beweglichen archäologischen Funde. Wie Burg Blauenstein in dieser Zeit ausgesehen hat können wir einer in das Jahr 1625 datierten detaillierten Beschreibung entnehmen. Ähnlich wie bei einer kürzer gefassten Beschreibung der Burg aus dem Jahr 1527 ist es uns auch bei der späteren Beschreibung nicht möglich, die einzelnen, bei der Grabung entdeckten Gebäude zu identifizieren. Hinsichtlich der Gliederung des Burgareals nehmen wir an, dass mit dem Terminus „obere Burg“ die Kernburg bezeichnet wird, der Begriff ,mittlere Burg“ bezieht sich auf den Zwinger, und die ,untere Burg“ bezeichnet die Vorburg an der Stelle des heutigen Schlosses. Die Beschreibung belegt eine bisher unbekannte Bebauung („eine Schule und neue Häuser“) im Bereich des Zwingers. Lokalisiert werden kann nur das obere Tor, das offenbar mit dem bis heute erhalten gebliebenen Eingang an der Ostseite identisch ist. Außer den für einen Adelshof der Renaissance typischen Objekten (Herrenhaus, Frauenzimmer) begegnen wir auf der Burg auch einem türkischen Bad, das zum derzeitigen Erkenntnisstand nicht lokalisiert werden kann.

Wahrscheinlich hat die Kernburg ab dem Ende des 17. Jahrhunderts ihre Wohnfunktion nach und nach eingebüßt. In weitaus geringerem Maße wurde bei der Grabung Keramik aus dem 18. Jahrhundert entdeckt. Das würde darauf hindeuten, dass die nordwestlichen und östlichen Terrassen erst in den siebziger Jahren des 19. Jahrhunderts angelegt wurden, als die Kernburg zu einem Park umgestaltet wurde. Das in der ersten Hälfte des 18. Jahrhunderts von Gabriel Balasso in der nördlichen Vorburg errichtete Barockschloss hat die Aufgabe einer Residenz übernommen. Sein Grundriss wird zusammen mit dem Grundriss der Kernburg vor ihrer Umgestaltung zu einem Park im Jahr 1862, bzw. 1866 von Karl Bergh festgehalten. Umgekehrt wurde der Grundriss der Burg mit der Kernburg bereits nach der Anlegung des Parks im Jahr 1889 von József Könyöki aufgezeichnet. 
Der vorliegende Beitrag entstand im Rahmen der von der Wissenschaftlichen Förderangentur des Ministeriums für Schulwesen, Wissenschaft, Forschung und Sport der Slowakischen Republik und der Slowakischen Akademie der Wissenschaften (VEGA) geförderten Projekte Nr. 1/0208/15: Der Mensch und die Berge im Lauf der Zeit - von urzeitlichen Burgwällen bis zu mittelalterlichen Burgen und des Exzellenz-Zentrums der Slowakischen Akademie der Wissenschaften: Burgen in der Slowakei. Interdisziplinäre Betrachtung des Phänomens der Burgen im Querschnitt und VEGA 1/0095/17: Krise und Kollaps an der Grenzscheide zwischen Mittelalter und Neuzeit (Sondierungen der Problematik im slowakischen Kontext).

PhDr. Ján Beljak, PhD., Archeologický ústav SAV, Vysunuté pracovisko Zvolen, Štúrova 2, SK 96053 Zvolen, Slovenská republika,beljak@savzv.sk

PhDr. Pavol Maliniak, PhD., Katedra histórie Filozofickej fakulty Univerzity Mateja Bela, Tajovského 40, SK 97401 Banská Bystrica, Slovenská republika,pavol.maliniak@umb.sk

Mgr. Michal Šimkovic, Mgr. Michal Šimkovic s. r. o., Kimovská 2341/4, SK 96001 Zvolen, Slovenská republika,simkovic.miso@gmail.com 
